\title{
Desensitization of the Neuronal 5-HT Carrier following Its Long-Term Blockade
}

\author{
Graciela Piñeyro, Pierre Blier, Trevor Dennis, and Claude de Montigny \\ Neurobiological Psychiatry Unit, McGill University, Department of Psychiatry, Montréal, Québec, Canada H3A 1A1
}

In vivo extracellular unitary recordings, in vitro ${ }^{3} \mathrm{H}-5$-hydroxytryptamine (5-HT) uptake, and ${ }^{3} \mathrm{H}$-paroxetine binding assays were used to assess the effect of acute and long-term administration of the 5-HT reuptake inhibitor paroxetine on the neuronal 5-HT transporter in the rat dorsal hippocampus. Recovery time of the firing activity of $\mathrm{CA}_{3}$ hippocampus pyramidal neurons following microiontophoretic application of 5-HT was used as an index of in vivo reuptake activity. In a first series of experiments, the acute intravenous administration of paroxetine and 5-HT denervation with the neurotoxin 5,7-dihydroxytryptamine produced a marked prolongation of the suppressant effect of $5-\mathrm{HT}$, indicating that reuptake into 5-HT terminals plays a significant role in terminating the action of microiontophoretically applied 5-HT. In a second series of experiments, rats were treated with paroxetine ( $10 \mathrm{mg} / \mathrm{kg} / \mathrm{d}$, s.c.) for 2 or $21 \mathrm{~d}$. In both treatment groups, there was a marked prolongation of the effect of microiontophoretically applied 5-HT; however, in rats treated for $2 \mathrm{~d}$, the prolongation was significantly greater than that observed in rats treated for $21 \mathrm{~d}$. After the $21 \mathrm{~d}$ treatment with paroxetine and a $48 \mathrm{hr}$ washout, the prolongation of the effect of microiontophoretically applied 5-HT by acute intravenous paroxetine was significantly reduced, suggesting a decrease in the number of 5-HT carriers. In keeping with this interpretation, following the same treatment regimen, there was a $50 \%$ and $60 \%$ reduction of the in vitro ${ }^{3} \mathrm{H}-5-\mathrm{HT}$ uptake in hippocampal and dorsal raphe slices, respectively, and a reduced effectiveness of paroxetine in blocking ${ }^{3} \mathrm{H}-5-\mathrm{HT}$ uptake in both regions. The determination of the binding parameters of ${ }^{3} \mathrm{H}$-paroxetine revealed that, in rats treated for $21 \mathrm{~d}$ with paroxetine (10 $\mathrm{mg} / \mathrm{kg} / \mathrm{d}, \mathrm{s.c}$.), following a $48 \mathrm{hr}$ washout $K_{d}$ values were unchanged but $B_{\max }$ values were reduced by $70 \%$ and $60 \%$ in hippocampal and cortical membranes, respectively.

[Key words: 5-HT uptake, 5-HT transporter, 5.HT carrier, ${ }^{3} \mathrm{H}$-paroxetine binding, downregulation, rat hippocampus]

\footnotetext{
Received June 29, 1993; revised Oct. 18, 1993; accepted Oct. 26, 1993.

We thank Raymond Mongeau for friendly advice throughout this work. We are grateful to Claude Bouchard and Normand Lavoie for technical assistance, Than Vo for computer programming, and Helen Camcron and Lisc Martin for sccretarial assistance. This work was supported by grants from the Medical Research Council of Canada (MRC) and Fonds de la Recherche en Santé du Québec (FRSQ). G.P. is a receipt of a Royal Victoria Hospital Research Institute Fellowship, P.B. of an MRC Scholarship, and T.D. of an FRSQ Scholarship.

Correspondence should be addressed to Graciela Piñeyro, Neurobiological Psychiatry Unit, McGill University, Department of Psychiatry, 1033 Pine Avenue West, Montréal, Québec, Canada H3A IAI.

Copyright (C) 1994 Society for Neuroscience $0270-6474 / 94 / 143036-12 \$ 05.00 / 0$
}

The 5-hydroxytryptamine (5-HT) reuptake process and 5-HT transporter have been widely studied in vitro using both ${ }^{3} \mathrm{H}-5$ HT uptake and radioligand binding techniques (Marcusson and Ross, 1990). In contrast, the characterization of 5-HT reuptake activity in vivo has not been so extensive, as studies have been mostly concerned with physiological, behavioral, or neurochemical consequences of reuptake inhibition (Fuller and Wong, 1990; Johnson, 1991). Using an in vivo electrophysiological paradigm, Wang et al. (1979) reported that 5-HT reuptake plays a significant role in terminating the action of microiontophoretically applied 5-HT onto latcral geniculatc and amygdaloid ncurons. However, the 5-HT reuptake process did not appear to play an important role in terminating the suppressant effect of microiontophoretically applied 5-HT onto $\mathrm{CA}_{3}$ pyramidal neurons (de Montigny et al., 1980).

Reports on the occurrence of a downregulation of the 5-HT transporter following long-term antidepressant treatment are controversial. Radioligand binding studies indicate that the neuronal 5-HT transporter is associated with ${ }^{3} \mathrm{H}$-imipramine (Langer and Raisman, 1983) and ${ }^{3} \mathrm{H}$-paroxetine binding sites (Habert et al., 1985; Mellerup and Plenge, 1986) and that repeated administration of several classes of antidepressant drugs downregulate ${ }^{3} \mathrm{H}$-imipramine (Plenge and Mellerup, 1982; Brunello et al., 1987), but not ${ }^{3} \mathrm{H}$-paroxetine, binding sites (Graham et al., 1987; Cheetham et al., 1991; Foy et al., 1991). This controversy may stem in part from the observation that while ${ }^{3} \mathrm{H}$ paroxetine binds to a single population of sites selectively located on 5-HT neurites (Marcusson et al., 1988; Hrdina et al., 1990), ${ }^{3} \mathrm{H}$-imipramine has been shown to label a heterogeneous population of sites in brain tissue (Reith et al., 1983; Marcusson et al., 1985). Recently, Kovachich et al. (1992), using ${ }^{3} \mathrm{H}-\mathrm{cy}-$ anoimipramine to label the 5-HT transporter, have concluded that different types of antidepressants do not exert consistent effects on the density of 5-HT reuptake sites.

The present study was thus undertaken to address the following issues that remained unsolved: (1) to devise a reliable method for measuring electrophysiologically in vivo 5-HT reuptake activity; (2) to assess functionally the possibility of a desensitization of the 5-HT carrier following long-term reuptake blockade; and (3) to correlate functional modifications with changes in the ${ }^{3} \mathrm{H}$-paroxetine binding parameters following long-term reuptake blockade with paroxetine.

\section{Materials and Methods}

Treatments. Male Sprague-Dawley rats (175-200 gm) were implanted subcutaneously with an osmotic minipump (Alza, Palo Alto, CA) that delivered 10 or $20 \mathrm{mg} / \mathrm{kg} / \mathrm{d}$ of paroxetine (SmithKline Beecham, Harlow, England) for 2 or $21 \mathrm{~d}$. The drug was dissolved in a $50 \%$ ethanol: water solution, and control rats were implanted with a minipump containing the vehicle. Unless otherwise specified, the experiments were 

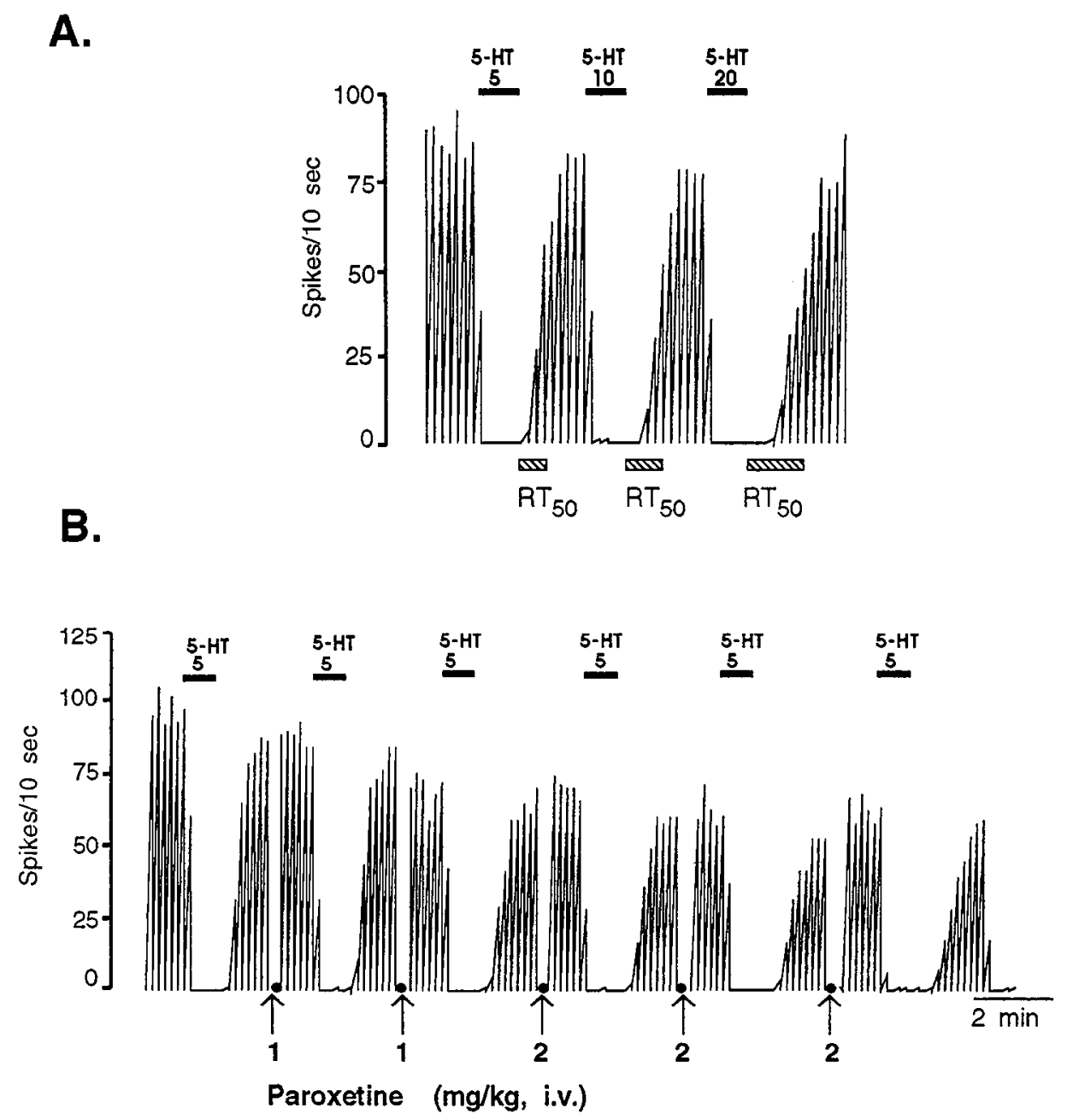

Figure 1. Integrated firing rate histograms showing the response of a representative dorsal hippocampus $C A$, pyramidal neuron to increasing $\mathrm{mi}$ croiontophoretic currents of 5-HT $(A)$ and the effect of successive injections of paroxetine at $10 \mathrm{~min}$ intervals on the response to microiontophoretic application of 5-HT $(B)$. The solid bars above each trace indicate the duration of application for which the ejection currents are given in $\mathrm{nA}$. The hatched bars below the histogram in $A$ indicate $\mathrm{RT}_{\mathbf{5 0}}$. This value is the time in seconds required by a neuron to recover by $50 \%$ its initial firing frequency calculated from the termination of the microiontophoretic application of drugs (left edge of the hatched bar). The dots at the bottom of the histogram in $B$ represent periods of $10 \mathrm{~min}$. Time scale applies to both traces. carried out with the osmotic minipump in place. Two weeks before the experiments, another series of rats received an intracerebroventricular injection of 5,7-dihydroxytryptamine (5,7-DHT; $200 \mu \mathrm{g}$ of free base in $20 \mu \mathrm{l}$ of $0.9 \% \mathrm{NaCl}$ and $0.1 \%$ ascorbic acid). This treatment has been shown to reduce 5-HT content in $\mathrm{CA}_{3}$ region by at least $90 \%$ (Gerson and Baldessarini, 1975). Desipramine ( $25 \mathrm{mg} / \mathrm{kg}$, i.p.) was administered $1 \mathrm{hr}$ before 5,7-DHT to protect noradrenaline neurons (Bjorklund et al., 1975). Control rats were injected with saline. All experiments were carried out under chloral hydrate anesthesia $(400 \mathrm{mg} / \mathrm{kg}$, i.p.).

Electrophysiological experiments. Extracellular unitary recordings were obtained from pyramidal neurons in the $\mathrm{CA}_{3}$ region of dorsal hippocampus. The microelectrode was descended $4 \mathrm{~mm}$ lateral and $4 \mathrm{~mm}$ anterior to lambda. Pyramidal neurons were identified by their highamplitude $(0.5-1.2 \mathrm{mV})$, long-duration $(0.6-1 \mathrm{msec})$ complex spike discharges alternating with simple spike activity (Kandel and Spencer, 1961). A leak or a small current of ACh $(0-5 \mathrm{nA})$ was used to activate the neurons within their physiological range (8-14 Hz; Ranck, 1975). Microiontophoretic applications were performed with five-barreled glass micropipettes that were pulled in a conventional manner and their tips broken back to 10-15 $\mu \mathrm{m}$ under microscopic control. The central barrel, filled with $2 \mathrm{M} \mathrm{NaCl}$ solution, was used for extracellular unitary recording. Three of the side barrels contained three of the following solutions: 5-HT creatinine sulfate $(5 \mathrm{~mm}$ in $200 \mathrm{~mm} \mathrm{NaCl}$, pH 4; Sigma, St. Louis, MO); norepinephrine (NE) (50 mM in $200 \mathrm{~mm} \mathrm{NaCl}, \mathrm{pH} \mathrm{4}$; Sigma); gepirone ( $25 \mathrm{~mm}$ in $200 \mathrm{~mm} \mathrm{NaCl}$, pH 4; Bristol-Myers Squibb, Wallingford, CT); or ACh (20 mm in $200 \mathrm{~mm} \mathrm{NaCl}$, pH 4; Sigma). The fourth side barrel, containing a $2 \mathrm{~m} \mathrm{NaCl}$ solution, was used for automatic current balancing. Ejection periods were always of $50 \mathrm{sec}$.

The responsiveness of $\mathrm{CA}_{3}$ pyramidal neurons to microiontophoretic application of drugs was assessed using $I \cdot T_{50}$ and $\mathrm{RT}_{50}$ values calculated by on-line computer with a $0.1 \mathrm{sec}$ resolution. The $I \cdot T_{\mathrm{so}}$ value represents the charge in nanocoulombs $(1 \mathrm{nC}=1 \mathrm{nA} \times 1 \mathrm{sec})$ required to obtain a $50 \%$ decrease of the firing rate of the neuron recorded and has been shown to provide an index of the neuronal responsiveness to the microiontophoretically applied drug (de Montigny and Aghajanian, 1977; de Montigny et al., 1980). The presynaptic component of neuronal responsiveness to microiontophoretic application of drugs was evaluated using the $\mathrm{RT}_{50}$ method. $\mathrm{RT}_{50}$ is defined as the time in seconds required by the neuron to recover $50 \%$ of its initial firing frequency from the termination of microiontophoretic application. The $\mathrm{RT}_{50}$ value has been shown to provide a reliable index of the in vivo activity of the NE reuptake process in the rat hippocampus (de Montigny et al., 1980; Gravel and de Montigny, 1987) and of the 5-HT carrier in the rat amygdala and lateral geniculate body (Wang et al., 1979).

Determination of in vitro ${ }^{3} \mathrm{H}-5-\mathrm{HT}$ uptake. For determination of in vitro ${ }^{3} \mathrm{H}-5$-HT uptake, animals were decapitated, their brains rapidly removed, and dissected on an ice-cold plate. Slices of $0.4 \mathrm{~mm}$ thickness from hippocampus or raphe region were prepared using a McIlwain chopper. They were incubated for $3 \mathrm{~min}$ at $37^{\circ} \mathrm{C}$ in a Krebs solution with various concentrations $(0-1000 \mathrm{nM})$ of paroxetine, and bubbled with a mixture of $95 \% \mathrm{O}_{2}$ and $5 \% \mathrm{CO}_{2}$. The composition of the Krebs solution was $118 \mathrm{~mm} \mathrm{NaCl}, 4.7 \mathrm{~mm} \mathrm{CaCl}, 1 \mathrm{~mm} \mathrm{NaH} \mathrm{PO}_{4}, 25 \mathrm{~mm}$ $\mathrm{NaHCO}_{3}, 11.1 \mathrm{~mm}$ glucose, $0.004 \mathrm{~mm} \mathrm{Na}$ EDTA, and $0.11 \mathrm{~mm}$ ascorbic acid. After the incubation period, ${ }^{3} \mathrm{H}-5-\mathrm{HT}$ (specific activity, $22.7 \mathrm{Ci} /$ mmol; New England Nuclear Research Products, Mississauga, Ontario, Canada) was added at a final concentration of $5 \mathrm{nM}, 20 \mathrm{nM}$, or $100 \mathrm{nM}$. Following a $3 \mathrm{~min}$ incubation period, uptake was terminated by transferring the slices to $5 \mathrm{ml}$ of ice-cold buffer, and they were then solubilized in $0.5 \mathrm{ml}$ of Soluene 350 (Packard Instruments, Downers Grove, IL). Radioactivity in the slices and the incubation medium was determined by liquid scintillation spectroscopy. Parallel experiments were carried out at $0^{\circ} \mathrm{C}$ as control for passive diffusion. All experiments were performed in duplicate and the amount of tritium actively captured by the tissue $\left(C_{A}\right)$ was calculated according to the formula $C_{A}=C_{T}-C_{P}$, where 


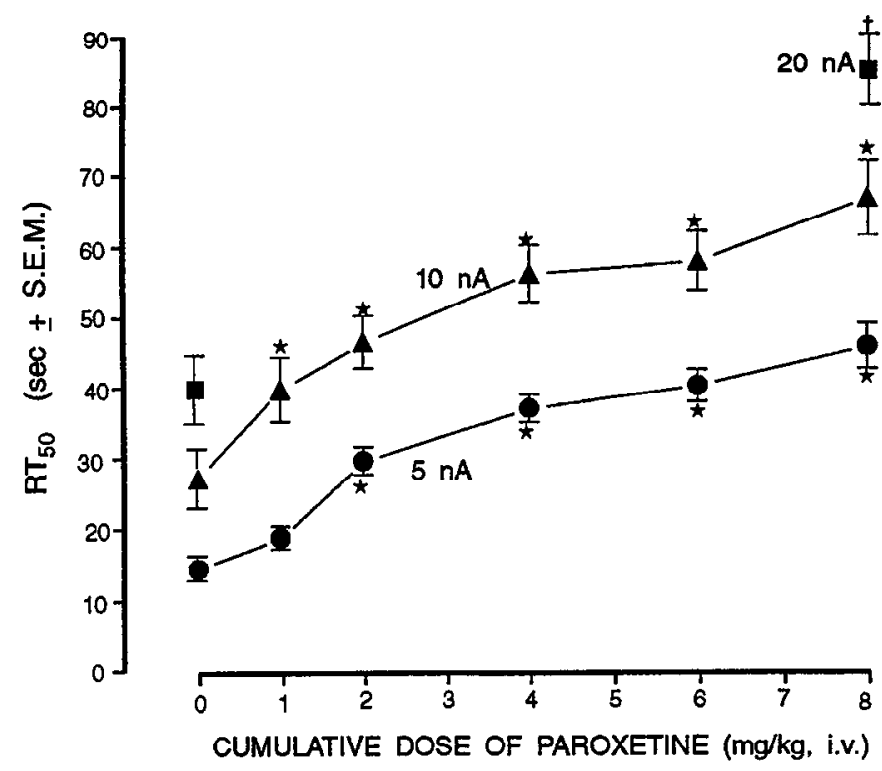

Figure 2. Effect of successive intravenous injections of paroxetine on the recovery time, expressed as $\mathrm{RT}_{50}$ values (means $\pm \mathrm{SEM}$ ), from microiontophoretic applications of 5 - $\mathrm{HT}$ with $5 \mathrm{nA}(\mathbf{0}), 10 \mathrm{nA}(\Delta)$, and $20 \mathrm{nA}(\square)\left(N=9\right.$ for all currents used). ${ }^{*}, p<0.001$, compared to preinjection value using the Student's paired $t$ test.

$C_{T}$ and $C_{P}$ are the tissue $\geq$ dium ratios of ${ }^{3} \mathrm{H}-5-\mathrm{HT}$ at $37^{\circ} \mathrm{C}$ and $0^{\circ} \mathrm{C}$, respectively. Inhibition of uptake was calculated by means of the formula $\%$ of inhibition $=\left[1-C_{\mathrm{AC}} / C_{\mathrm{AP}}\right] \times 100$, where $C_{\mathrm{AC}}$ and $C_{\mathrm{AP}}$ are the amounts of actively captured ${ }^{3} \mathrm{H}-5-\mathrm{HT}$ in a medium with or without paroxetine, respectively.

$\mathrm{IC}_{50}$ values for the uptake of ${ }^{3} \mathrm{H}-5-\mathrm{HT}$ were determined by computer analysis (GRAPHPAD, Graphpad Software, San Diego, CA) from concentration-effect curves based on four concentrations of paroxetine.

${ }^{3} \mathrm{H}$-paroxetine binding assays. Binding assays using ${ }^{3} \mathrm{H}$-paroxetine $(25$ $\mathrm{Ci} / \mathrm{mmol}$; New England Nuclear Research Products) were performed according to a previously described protocol (Marcusson et al., 1988). Forty-eight hours after the removal of the osmotic minipump rats were decapitated, brains dissected, and cortex and hippocampus immediately frozen and kept at $-70^{\circ} \mathrm{C}$ until the binding assays were carried out. Membranes were prepared by homogenizing brain tissue in $15 \mathrm{ml}$ of ice-cold buffer ( $50 \mathrm{~mm}$ Tris $\mathrm{HCl}, 120 \mathrm{~mm} \mathrm{NaCl}, 5 \mathrm{~mm} \mathrm{KCl}$; $\mathrm{pH} 7.4$ ) and centrifuging at $48,000 \times g$ for $10 \mathrm{~min}$ at $4^{\circ} \mathrm{C}$. The resulting pellet was suspended in $15 \mathrm{ml}$ of buffer and centrifuged. The final pellet was suspended to a final tissue concentration of 40-60 $\mu \mathrm{g}$ protein $/ \mathrm{ml}$ (approximately $0.75 \mathrm{mg}$ wet weight $/ \mathrm{ml}$ ) in the binding assay. The homogenates were incubated with ${ }^{3} \mathrm{H}$-paroxetine $(0.03-2 \mathrm{nM})$ at $22^{\circ} \mathrm{C}$ in a final volume of $1600 \mu \mathrm{l}$ for $60 \mathrm{~min}$. Incubations were terminated by addition of $4 \mathrm{ml}$ ice-cold buffer and filtration through Whatman GF/C filters using a 24-channel cell harvester. Filters were then washed with four 4 $\mathrm{ml}$ rinses in cold buffer. Radioactivity trapped by the filters was determined by liquid scintillation spectroscopy (Beckman Counter LS 6000 $\mathrm{SE}$, Beckman Instruments, Fullerton, CA). Nonspecific binding was estimated in the presence of $100 \mu \mathrm{M}$ 5-HT. Binding was analyzed using the curve-fitting program LIGAND (G. A. McPherson, Elsevier-Biosoft, Cambridge, UK).

Statistical analysis. Results were expressed throughout as means \pm SEM. When two means were compared, statistical significance of their difference was assessed using the two-tailed paired or nonpaired Student's $t$ tests as indicated. For multiple comparisons, one-way or twoway ANOVA was used for independent and paired samples, respectively.

\section{Results}

Effect of acute intravenous administration of paroxetine on the recovery time from microiontophoretic applications of 5-HT

The duration of suppression following 5-HT applications was assessed in naive rats using increasing currents for applying
A.
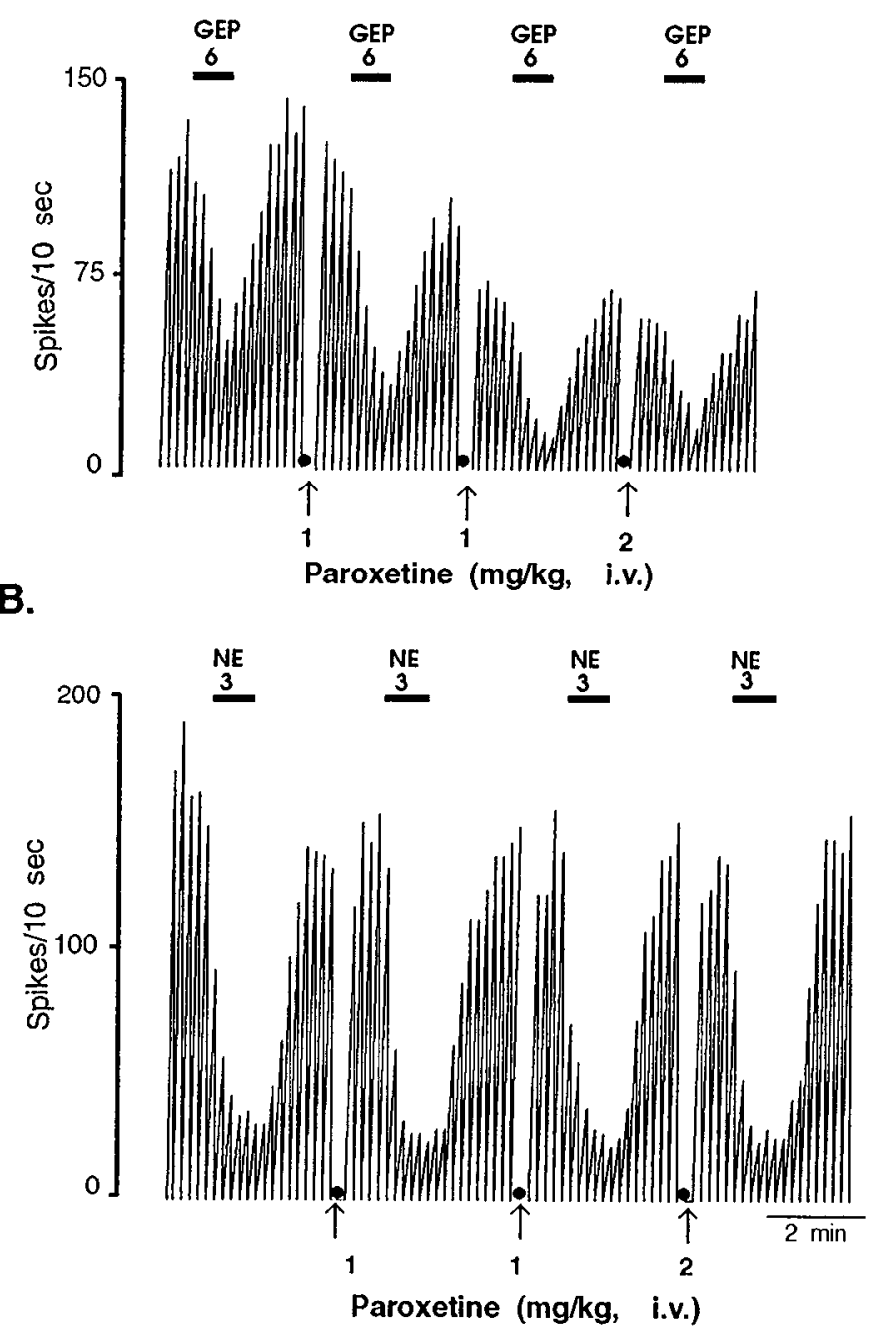

Figure 3. Integrated firing rate histograms of dorsal hippocampus $\mathrm{CA}_{3}$ pyramidal neurons showing the effect of successive injections of paroxetine at $10 \mathrm{~min}$ intervals on the response of a dorsal hippocampus pyramidal neuron to microiontophoretic application of gepirone $(A)$ and NE $(B)$. Dots at the bottom of each histogram represent periods of $10 \mathrm{~min}$. Time scale applies to both tracings.

5-HT. The recovery time ( $\mathrm{RT}_{50}$ value) was proportional to the current used: 5,10 , and $20 \mathrm{nA}$ applications yielded $\mathrm{RT}_{50}$ values of $16 \pm 2,27 \pm 4$, and $41 \pm 5 \mathrm{sec}$, respectively $(n=9$; Fig. $1 A$ ). Following intravenous administration of successive 1-2 $\mathrm{mg} / \mathrm{kg}$ doses of paroxetine (cumulative doses of 2, 4, 6, and 8 $\mathrm{mg} / \mathrm{kg}$ ), the effect of microiontophoretically applied 5-HT was dose-dependently prolonged (Figs. $1 B, 2$ ). At the highest dose of paroxetine used ( $8 \mathrm{mg} / \mathrm{kg}$, i.v.), the $\mathrm{RT}_{\text {so }}$ values for $5 \mathrm{nA}, 10$ $\mathrm{nA}$, and $20 \mathrm{nA}$ applications were increased by $206 \%, 145 \%$, and $110 \%$, respectively.

In order to confirm the selectivity of paroxetine for the 5-HT carrier in this paradigm, the effect of paroxetine was assessed on the recovery from microiontophoretic applications of the 5-HT $\mathrm{HA}_{1 \mathrm{~A}}$ agonist gepirone and NE, neither of which are substrates for the 5-HT transporter. In contrast to the prolongation of the effect observed for 5-HT, the $\mathrm{RT}_{50}$ values for these two compounds were not affected by successive doses of paroxetine (Fig. 3 , Table 1). While in the dose range of $1-4 \mathrm{mg} / \mathrm{kg}$, intravenous 
A.

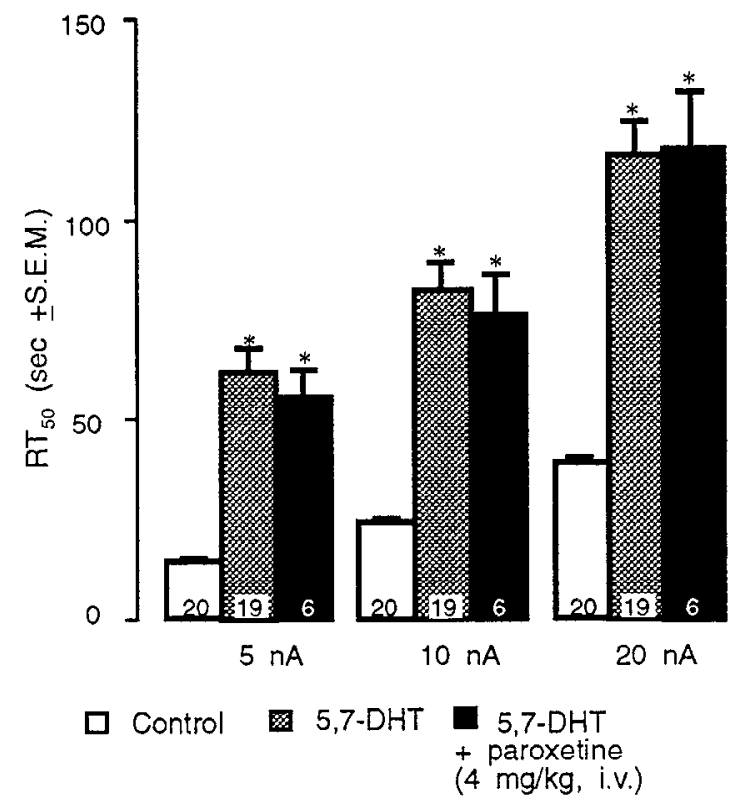

B.

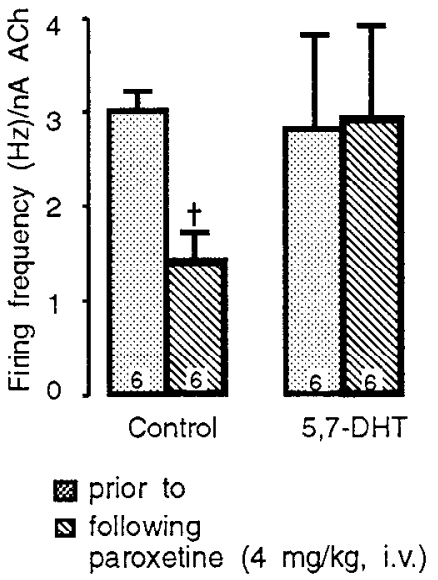

Figure 4. A, Recovery time, expressed as $\mathrm{RT}_{\text {so }}$ values (means $\pm \mathrm{SEM}$ ), of dorsal hippocampus $\mathrm{CA}_{3}$ pyramidal neurons from microiontophoretic applications of 5-HT in control rats and in rats treated with 5,7-DHT, before and after intravenous administration of 4 $\mathrm{mg} / \mathrm{kg}$ of paroxetine. ${ }^{*}, p<0.001 \mathrm{com}$ pared to control values using two-tailed Student's $t$ test. $B$, Effect of intravenous paroxetine on pyramidal neuron firing frequency in control and 5,7-DHT-lesioned rats. $\dagger, p<0.01$ using two-tailed paired Student's $t$ test. The number of neurons tested is given at the bottom of each column. administration of paroxetine dose-dependently increased $\mathrm{RT}_{50}$ values of 5 -HT applications $(r=0.8, p<0.001), \mathrm{RT}_{50}$ values for NE and gepirone were not correlated with the dose of paroxetine administered $(r=0.01, p=0.8)$.

\section{Effect of 5-HT denervation on the recovery from} microiontophoretic applications of 5-HT

The prolongation of the recovery time from microiontophoretic applications of 5-HT, following acute 5-HT reuptake blockade, in the absence of a modification of its initial effectiveness $[I$. $T_{50}$ values: $23 \pm 3 \mathrm{nC}$ prior to, and $25 \pm 4 \mathrm{nC}$ following, paroxetine ( $4 \mathrm{mg} / \mathrm{kg}$, i.v.; $n=14)$ ], suggested a pure presynaptic effect of paroxetine. This interpretation relied, however, on the assumption that the recovery of the firing rate of $\mathrm{CA}_{3}$ pyramidal neurons from microiontophoretic applications of 5-HT is exerted mainly by the 5-HT transporters located on 5-HT terminals. To verify this hypothesis, the recovery from 5-HT applications was assessed in 5,7-DHT-lesioned rats. As expected, 5-HT denervation markedly prolonged the effect of 5-HT: the $\mathrm{RT}_{50}$ values were increased by $324 \%, 262 \%$, and $197 \%$ for 5 $\mathrm{nA}, 10 \mathrm{nA}$, and $20 \mathrm{nA}$ applications, respectively (Fig. $4 A$ ). In-

\begin{tabular}{|c|c|c|c|}
\hline \multirow{2}{*}{$\begin{array}{l}\text { Cumula- } \\
\text { tive dose } \\
\text { of paro- } \\
\text { xetine } \\
\text { (mg/kg, } \\
\text { i.v.) }\end{array}$} & \multicolumn{3}{|c|}{$\mathrm{RT}_{50}(\mathrm{~s} \pm \mathrm{SEM})$} \\
\hline & $\begin{array}{l}\text { Gepirone } \\
(n=3)\end{array}$ & $\begin{array}{l}\mathrm{NE} \\
(n=3)\end{array}$ & $\begin{array}{l}5-\mathrm{HT} \\
(n=3) \\
\end{array}$ \\
\hline 0 & $23 \pm 10$ & $35 \pm 12$ & $10 \pm 2$ \\
\hline 1 & $18 \pm 4$ & $35 \pm 15$ & $14 \pm 5$ \\
\hline 2 & $18 \pm 5$ & $37 \pm 12$ & $26 \pm 4^{*}$ \\
\hline 4 & $20 \pm 11$ & $35 \pm 9$ & $39 \pm 4^{*}$ \\
\hline
\end{tabular}

${ }^{*} P<0.01$ using the two-tailed Student's $t$ test. terestingly, as shown in Figure $4 A$, the injection of paroxetine (4 $\mathrm{mg} / \mathrm{kg}$, i.v.) in 5,7-DHT-lesioned rats did not produce a further increase in $\mathrm{RT}_{50}$, indicating that pretreatment with 5,7DIIT had produced a complete denervation and that the effect of paroxetine observed in intact rats (Figs. 1, 2) was entirely attributable to the blockade of the 5-HT transporters located on 5-HT terminals.

In intact rats, intravenous administration of paroxetine per se reduced pyramidal neuron firing frequency. Consequently, the microiontophoretic current of the $\mathrm{ACh}$ had to be increased from $4 \pm 0.7$ to $9 \pm 0.8 \mathrm{nA}(n=6)$ to restore the firing rate to its preinjection level. Brunel and de Montigny (1987) have previously demonstrated that $\mathrm{ACh}$ does not alter the response of pyramidal neurons to 5-HT. In 5,7-DHT-lesioned rats, paroxetine had no effect on the firing frequency of pyramidal neurons $(n=6$; Fig. $4 B)$.

It is also noteworthy that 5,7-DHT lesion and administration of paroxetine $(10 \mathrm{mg} / \mathrm{kg} / \mathrm{d}$, s.c.) for $2 \mathrm{~d}$ yielded nearly identical $\mathrm{RT}_{50}$ values. When the $\mathrm{RT}_{50}$ values from 5 - $\mathrm{HT}$ applications were

Table 2. Effect of short-term paroxetine administration and 5,7DHT lesion on the recovery from microiontophoretic applications of 5-HT

\begin{tabular}{rllll}
$\begin{array}{l}\text { Cur- } \\
\text { rent } \\
(\mathrm{nA})\end{array}$ & $\begin{array}{l}\text { Control } \\
(n=19)\end{array}$ & $\begin{array}{l}5,7-\mathrm{DHT} \\
(n=19)\end{array}$ & $\begin{array}{l}\text { Paroxetine } \\
\text { low dose* } \\
(n=15)\end{array}$ & $\begin{array}{l}\text { Paroxetine } \\
\text { high dose** } \\
(n=17)\end{array}$ \\
\hline 5 & $14.5 \pm 1$ & $61.5 \pm 6^{* * *}$ & $62.3 \pm 6^{* * *}$ & $66.2 \pm 3^{* * *}$ \\
10 & $24.3 \pm 1$ & $82.6 \pm 7^{* * *}$ & $88.8 \pm 7^{* * *}$ & $85.8 \pm 3^{* * *}$ \\
20 & $39.0 \pm 2$ & $116.0 \pm 8^{* * *}$ & $122.0 \pm 9^{* * *}$ & $109.4 \pm 4^{* * *}$
\end{tabular}

In paroxetine treated rats the experiments were performed with the osmotic pump in place.

$* 10 \mathrm{mg} / \mathrm{kg} /$ day, s.c. $\times 2$ days.

** $20 \mathrm{mg} / \mathrm{kg} /$ day, s.c. $\times 2$ days.

*** $p<0.001$ using two-tailed Student's $t$ test. 
A. CONTROL

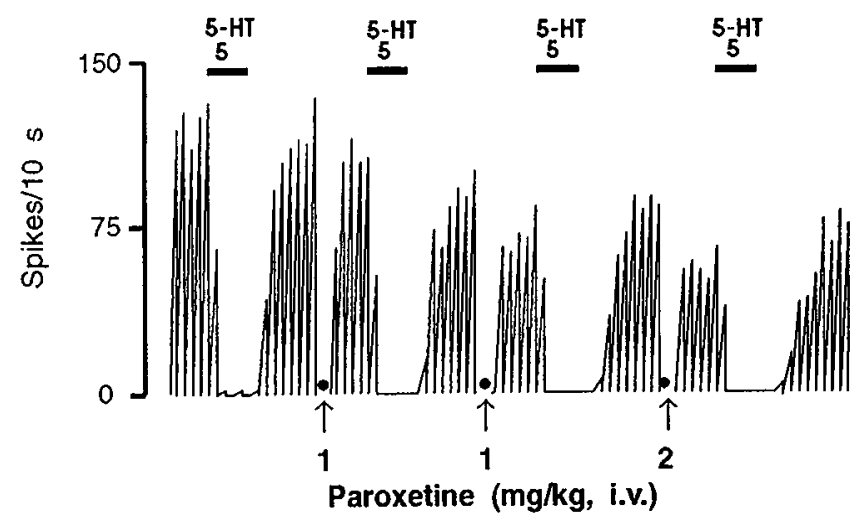

B. PAROXETINE (10 mg/kg/day, s.c. $\times 21$ days) + $48 \mathrm{~h}$ washout

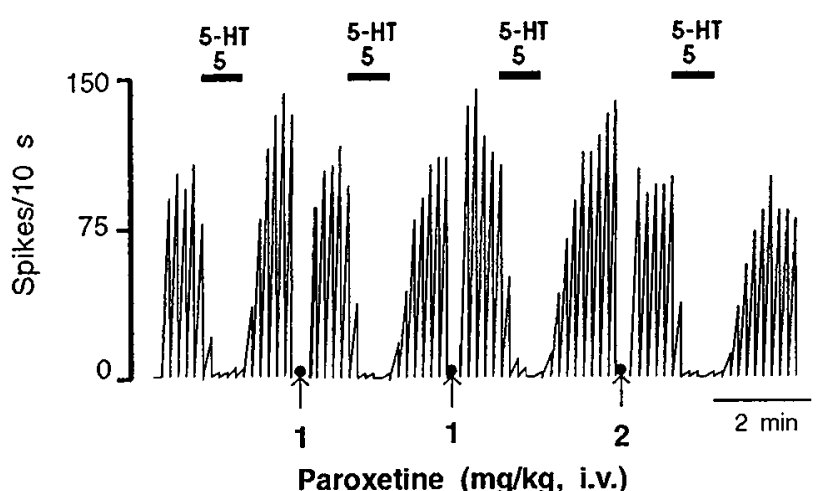

Figure 5. Integrated firing rate histograms showing the response of dorsal hippocampus $\mathrm{CA}_{3}$ pyramidal neurons to microiontophoretic applications of 5-HT in a control rat $(A)$ and a long-term paroxetinetreated rat $(B)$, following successive intravenous injections of paroxetine at $10 \mathrm{~min}$ intervals. Rats were implanted subcutaneously with an osmotic minipump which delivered either vehicle or paroxetine. After 21 $\mathrm{d}$ the minipump was removed and a $48 \mathrm{hr}$ washout period was allowed. Time scale applies to both traces.

assessed in rats that were still carrying the osmotic minipump during the experiment, this parameter was increased by $320 \%$, $270 \%$, and $212 \%$ for 5,10 , and $20 \mathrm{nA}$ currents, respectively (as compared to $324 \%, 262 \%$, and $197 \%$ for the same currents in 5,7-DHT-lesioned rats). This suggests that, at a dose of paroxctinc of $10 \mathrm{mg} / \mathrm{kg} / \mathrm{d}$, all the $5-\mathrm{HT}$ transporters were blocked,

\begin{tabular}{|c|c|c|c|}
\hline \multirow{2}{*}{$\begin{array}{l}\text { Cur- } \\
\text { rent } \\
\text { (nA) }\end{array}$} & \multicolumn{2}{|c|}{ Dose of paroxetine (mg/kg, i.v.) } & \multirow[b]{2}{*}{$p^{* * *}$} \\
\hline & $\begin{array}{l}\text { Control } \\
(n=9)\end{array}$ & $\begin{array}{l}\text { Paroxetine** } \\
(n=7)\end{array}$ & \\
\hline 5 & $1.7 \pm 0.2$ & $3.2 \pm 0.6$ & $<0.03$ \\
\hline 10 & $2.4 \pm 0.2$ & $4.1 \pm 0.4$ & $<0.01$ \\
\hline 20 & $2.4 \pm 0.3$ & $4.0 \pm 0.7$ & $<0.05$ \\
\hline
\end{tabular}

${ }^{*} \mathrm{ED}_{50}$ was calculated as the dose of paroxetine necessary to increase $\mathrm{RT}_{50}$ by $50 \%$. $* * 10 \mathrm{mg} / \mathrm{kg} /$ day, s.c. $\times 21$ days.

*** Using the two-tailed Student's $t$ test.
A.

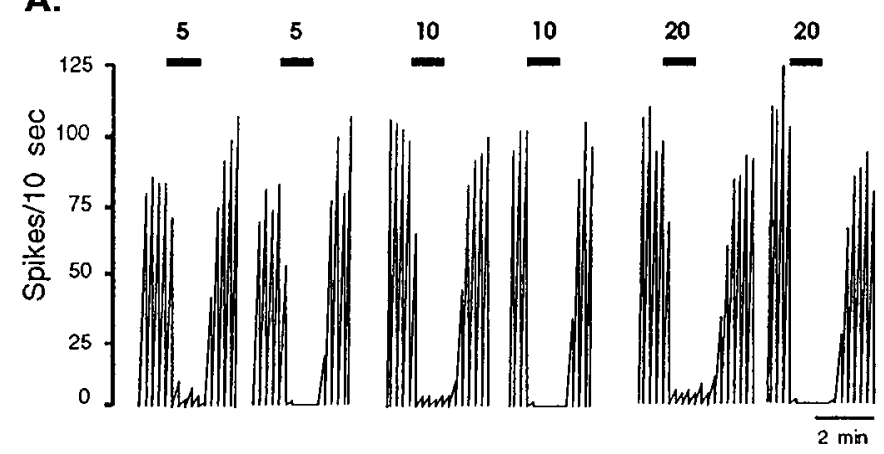

B.

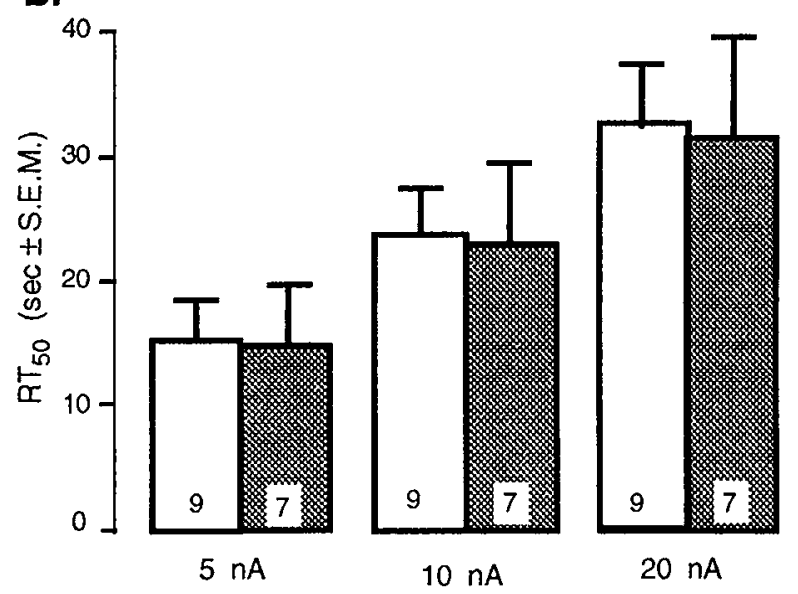

$\square$ Control

Paroxetine $(10 \mathrm{mg} / \mathrm{kg} /$ day, s.c. $\times 21$ days $)+48 \mathrm{~h}$ washout

Figure 6. $A$, Integrated firing rate histograms illustrating the response of dorsal hippocampus $\mathrm{CA}_{3}$ pyramidal neurons in a control and a longterm paroxetine-treated rat $48 \mathrm{hr}$ after the removal of the osmotic pump. Each current is applied alternatively in the control rat and the paroxetine-treated rat. $B$, Recovery time expressed as $\mathrm{RT}_{s 0}$ values (mean \pm SEM) of dorsal hippocampus pyramidal neurons from microiontophoretically applied 5-HT in control rats and in rats treated with paroxetine for $21 \mathrm{~d}$. Note that $\mathrm{RT}_{50}$ values for the $5 \mathrm{nA}$ current are significantly smaller than for the $20 \mathrm{nA}$ current and this difference is maintained after long-term paroxetine administration $(p<0.001)$. Number of neurons tested is given at the bottom of each column.

thus simulating denervation. Furthermore, when the dose of paroxetine was doubled $(20 \mathrm{mg} / \mathrm{kg} / \mathrm{d} \times 2 \mathrm{~d}), \mathrm{RT}_{50}$ values did not further increase (Table 2), thereby confirming that the 10 $\mathrm{mg} / \mathrm{kg} / \mathrm{d}$ dose of paroxetine maximally inhibits 5 -HT reuptake.

\section{Effect of long-term administration of paroxetine on the} recovery time from microiontophoretic applications of 5-HT

To test the effect of long-term reuptake blockade on the 5-HT transporter, the effectiveness of successive intravenous doses $\left(1-2 \mathrm{mg} / \mathrm{kg}\right.$ ) of paroxetine to prolong $\mathrm{RT}_{50}$ values was assessed in control and paroxetine-treated rats $(10 \mathrm{mg} / \mathrm{kg} / \mathrm{d}$, s.c. $\times 21 \mathrm{~d})$ following a $48 \mathrm{hr}$ washout period to ensure complete drug elimination. As exemplified in Figure 5, the effectiveness of acute intravenous paroxetine was reduced in the paroxetine-treated group. Before the injection of paroxetine, the $\mathrm{RT}_{50}$ values were similar in treated and in control rats (Fig. 6), indicating, first, that the reuptake process was no longer blocked after the washout period, and second, that at the concentrations attained with the different microiontophoretic currents of 5-HT used, the ability of 5-HT terminals to take up 5-HT was unchanged after 


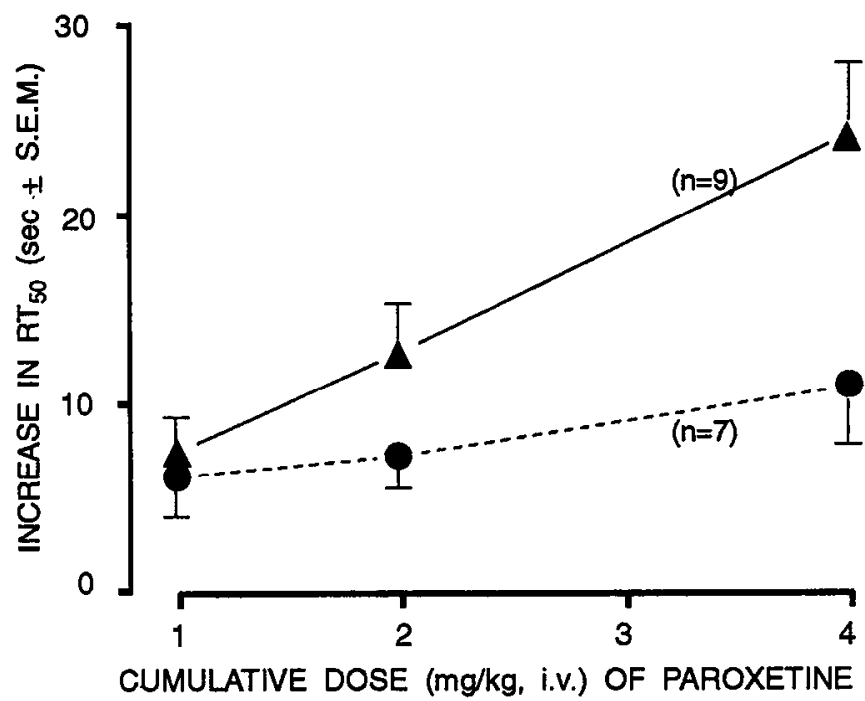

Figure 7. Effect of successive injections of paroxetine on the recovery time from $5 \mathrm{nA}$ microiontophoretic applications of 5-HT in control rats (A) and in rats treated with paroxetine $(10 / \mathrm{mg} / \mathrm{kg} / \mathrm{d}$, s.c. $\times 21 \mathrm{~d})$ following $48 \mathrm{hr}$ washout $(\bullet)$. Values are expressed as increase in $\mathrm{RT}_{50}$ (mean \pm SEM). $p<0.05$, comparing the two curves by ANOVA.

long-term blockade by paroxetine. The first dose of paroxetine $\left(1 \mathrm{mg} / \mathrm{kg}\right.$, i.v.) increased the $\mathrm{RT}_{50}$ values to a similar extent in control and long-term paroxetine-treated rats. However, subsequent cumulative doses of 2 and $4 \mathrm{mg} / \mathrm{kg}$ produced smaller effects in long-term paroxetine-treated rats than in controls (Figs. 5,7 ), indicating a decreased efficacy of intravenous paroxetine in blocking 5-HT reuptake following long-term paroxetine treatment. For all currents used, the dose of paroxetine required to increase $\mathrm{RT}_{30}$ values by $50 \%\left(\mathrm{ED}_{50}\right)$ was doubled in long-term paroxetine-treated rats (Table 3 ).

To investigate further the induction of a "tolerance" by longterm paroxetine administration, the suppressant effect of 5-HT was determined in control rats and in rats treated with paroxetine $(10 \mathrm{mg} / \mathrm{kg} / \mathrm{d}$, s.c.) for 2 or $21 \mathrm{~d}$ without removing the osmotic pump. For all currents used, recovery from microiontophoretic applications of 5-HT was prolonged in both treated groups, but to a significantly lesser extent in long-term- than in short-term-treated rats (Fig. 8). The $\mathrm{RT}_{50}$ values from 5, 10, and $20 \mathrm{nA}$ applications of 5 -HT were increased by $377 \%, 300 \%$, and $198 \%$ in $2 \mathrm{~d}$ paroxetine-treated rats, and by $254 \%, 196 \%$, and $149 \%$ in $21 \mathrm{~d}$ paroxetine-treated rats (Fig. 9).

Recovery from microiontophoretic applications of gepirone was unchanged by long-term administration of paroxetine, in keeping with the fact that it is not a substrate for the 5-HT transporter. $\mathrm{RT}_{50}$ values from 4 and $10 \mathrm{nA}$ applications of gepirone were $28 \pm 4 \mathrm{sec}$ and $53 \pm 8 \mathrm{sec}$ in control rats, and 24 $\pm 4 \mathrm{sec}$ and $50 \pm 6 \mathrm{sec}$ in rats treated with paroxetine for 21 $\mathrm{d}$. The initial responsiveness $\left(I \cdot T_{50}\right.$ values) to microiontophoretic applications of gepirone and of 5-HT was also unchanged following long-term paroxetine treatment, ruling out the possibility that the reduced effectiveness of acute paroxetine to prolong the effect of 5-HT could be ascribed to a decrease in neuronal responsiveness to the activation of postsynaptic $5-\mathrm{HT}_{1 \mathrm{~A}}$ receptors. For $5-\mathrm{HT}$, respective $I \cdot T_{50}$ values for 5 and $10 \mathrm{nA}$ applications were $24 \pm 3 \mathrm{nC}$ and $39 \pm 4 \mathrm{nC}$ in control rats $(n$ $=18$ ), and $23 \pm 2 \mathrm{nC}$ and $42 \pm 3 \mathrm{nC}$ following the $21 \mathrm{~d}$ paroxetine treatment $(n=18)$.
A. CONTROL

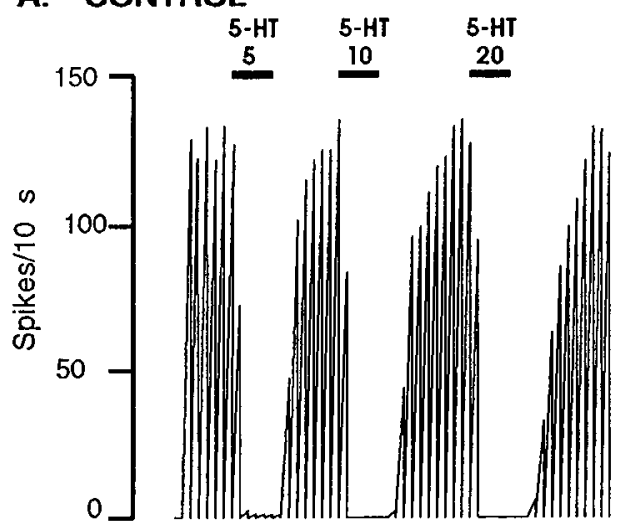

B. PAROXETINE (10 $\mathrm{mg} / \mathrm{kg} /$ day, s.c. $\times 2$ days)

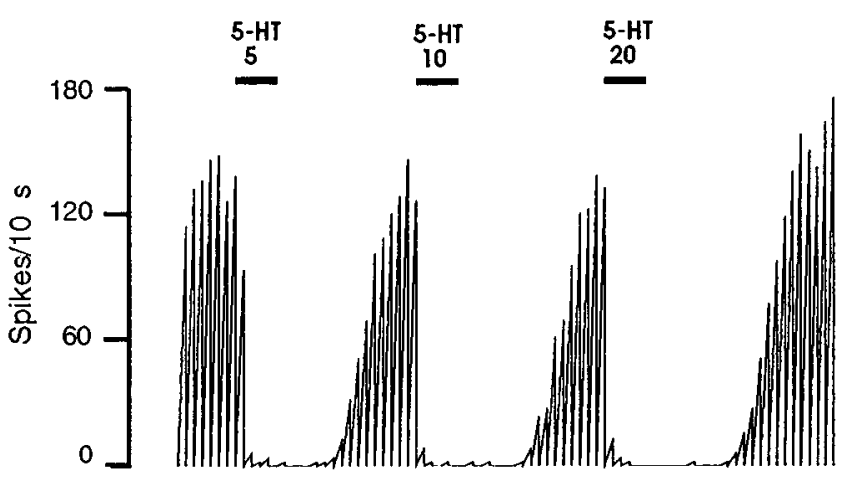

C. PAROXETINE (10 mg/kg/day, s.c. $\times 21$ days $)$

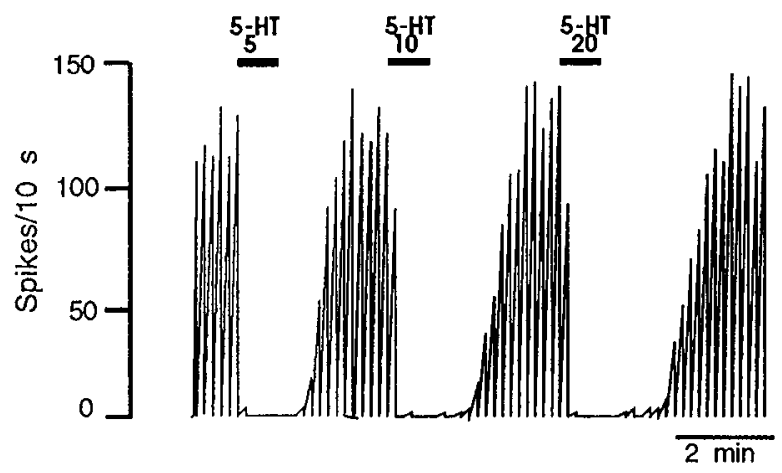

Figure 8. Integrated firing rate histograms showing the response of $\mathrm{CA}_{3}$ dorsal hippocampus pyramidal neurons to microiontophoretically applied 5-HT in a control rat $(A)$ and in rats treated with paroxetine $(10 \mathrm{mg} / \mathrm{kg} / \mathrm{d}$, s.c.) for $2 \mathrm{~d}(B)$ or $21 \mathrm{~d}(C)$. In $B$ and $C$, the experiments were carried out with the minipump in place.

Effect of long-term paroxetine administration on in vitro ${ }^{3} \mathrm{H}$ 5-HT uptake

The following series of experiments were carried out to verify in vitro the induction of desensitization of the 5-HT transporter by long-term paroxetine administration. In control experiments, increasing the concentration of paroxetine in the incubation medium caused a concentration-dependent reduction in the amount of radioactivity captured by the slices. In slices from 5,7-DHT-lesioned rats, the uptake of ${ }^{3} \mathrm{H}-5-\mathrm{HT}$ was reduced by 


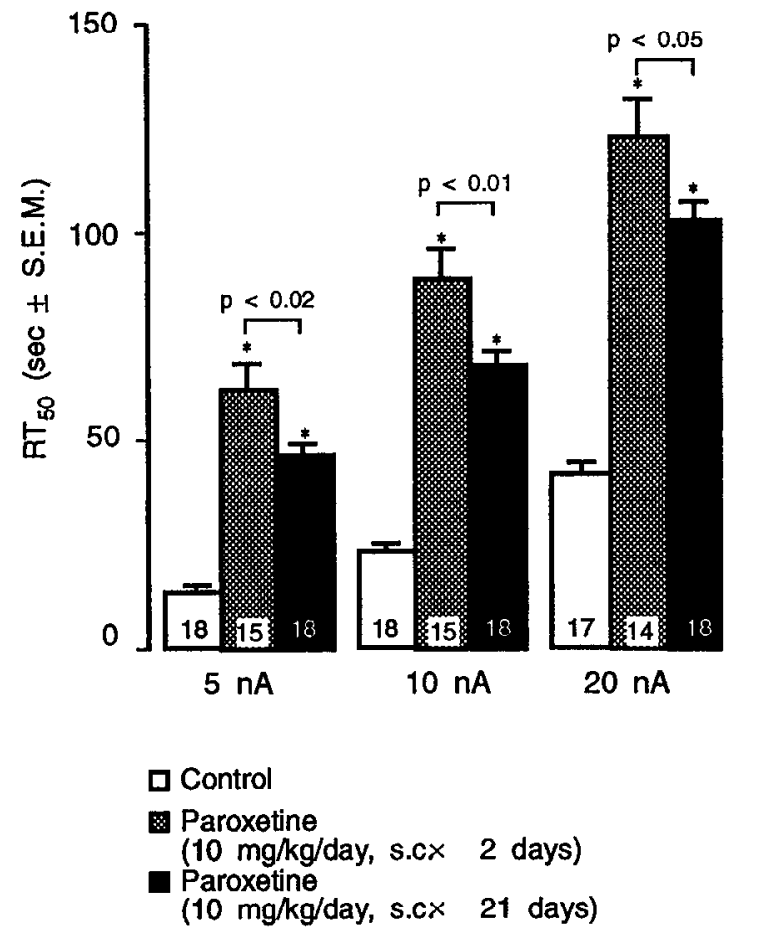

Figure 9. Recovery time, expressed as $\mathrm{RT}_{50}$ values (mean $\pm \mathrm{SEM}$ ), of dorsal hippocampus pyramidal neurons from microiontophoretically applied 5-HT in control rats and in rats treated with paroxetine $(10 \mathrm{mg}$ $\mathrm{kg} / \mathrm{d}$, s.c.) for 2 or $21 \mathrm{~d}$. The number of neurons tested is given at the bottom of each column. *, $p<0.001$ compared to control values using two-tailed Student's $t$ test. $p$ values indicated on the figure also were obtained using the nonpaired Student's $t$ test.

$70 \%$ (Fig. 10). Moreover, the incubation with increasing paroxetine concentrations did not produce further inhibition (Fig. 10). As ${ }^{3} \mathrm{H}-5$-HT uptake in control slices incubated with the highest paroxetine concentration $(1000 \mathrm{nM})$ was not significantly different from that observed after 5,7-DHT lesion, it can be assumed that maximal blockade of 5-HT uptake sites was attained at this concentration.

In slices from control rats, paroxetine in the incubation medium was more effective in blocking reuptake using a $100 \mathrm{~nm}$ than a 5 nM concentration of ${ }^{3} \mathrm{H}-5-\mathrm{HT}$ (Fig. $\left.11 D, F\right)$. From each of these paroxetine concentration-effect curves, the concentration of paroxetine inducing $50 \%$ of the maximal inhibition (attained with $1000 \mathrm{~nm}$ paroxetine) was determined. Paroxetine was six times more potent in blocking reuptake when the ${ }^{3} \mathrm{H}$ 5 -HT concentration in the incubation medium was high (100 nM) than when it was low $(5 \mathrm{nM})$ : respective calculated $\mathrm{IC}_{50}$ values were $18 \mathrm{~nm}$ and $107 \mathrm{~nm}$.

Following a $48 \mathrm{hr}$ washout period, in slices incubated with $100 \mathrm{~nm}{ }^{3} \mathrm{H}-5-\mathrm{HT}$, radioactivity taken up by the tissue was reduced by $50 \%$ in the long-term paroxetine-treated group. This effect was significant in slices incubated with $100 \mathrm{~nm}{ }^{3} \mathrm{H}-5-\mathrm{HT}$ and with paroxetine concentrations lower than $1000 \mathrm{~nm}$ (Fig. $11 A$ ).

Following long-term treatment with paroxetine, the in vitro effectiveness of paroxetine to block 5-HT uptake was reduced by $43 \%$, thus confirming results from electrophysiological experiments reported above. However, this in vitro effect was only seen when incubation was carried out in the presence of $5 \mathrm{~nm}$ ${ }^{3} \mathrm{H}-5-\mathrm{HT}$ (Fig. $11 \mathrm{~F}$ ). When slices were incubated with $20 \mathrm{nM}$

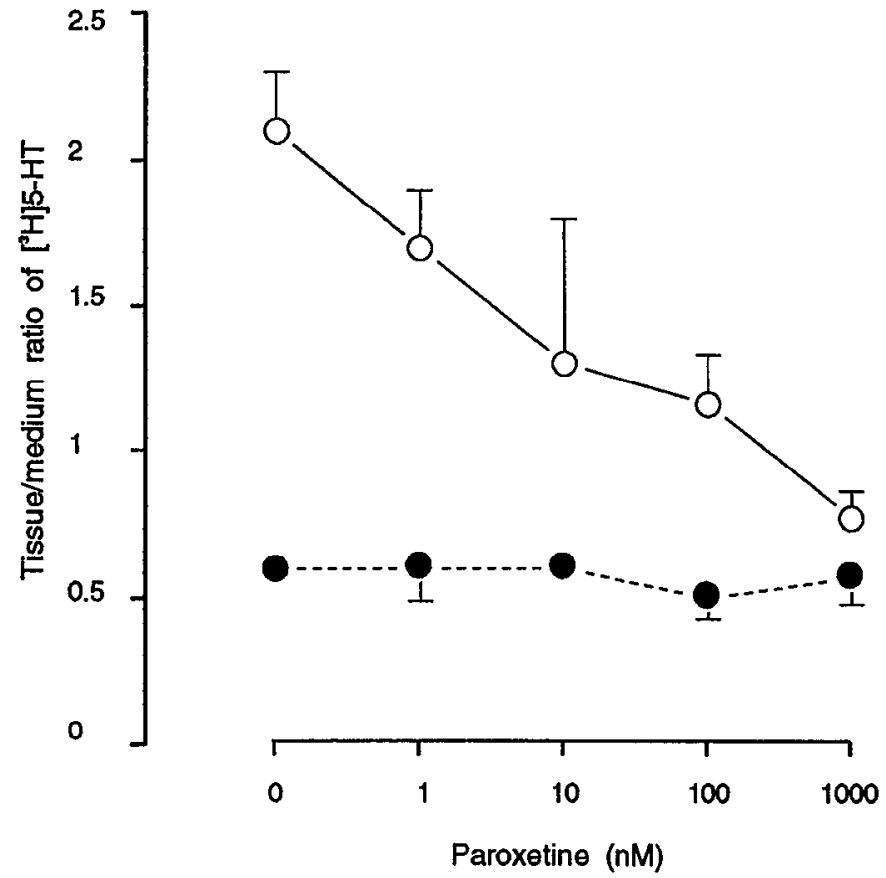

Figure 10. Effect of increasing concentrations of paroxetine on ${ }^{3} \mathrm{H}-5$ HT uptake in hippocampal slices of control $(0)$ and 5,7-DHT-lesioned rats (O), $n=3$ in each group. $p<0.001$ comparing both curves by ANOVA.

${ }^{3} \mathrm{H}-5-\mathrm{HT}$, long-term paroxetine treatment did not have any detectable effect (Fig. $11 B, E$ ). Moreover, it is noteworthy that after long-term paroxetine treatment the difference in $\mathrm{IC}_{50}$ for paroxetine at different ${ }^{3} \mathrm{H}-5-\mathrm{HT}$ concentrations was abolished. Calculated $\mathrm{IC}_{50}$ values were $14 \mathrm{nM}$ and $13 \mathrm{nM}$ for ${ }^{3} \mathrm{H}-5-\mathrm{HT}$ concentrations of $5 \mathrm{nM}$ and $100 \mathrm{nM}$, respectively.

The effect of long-term reuptake blockade was also assessed in slices from the raphe region. It induced changes similar to those observed in the hippocampus: ${ }^{3} \mathrm{H}-5-\mathrm{HT}$ uptake was reduced by $60 \%$ (Fig. $12 A$ ) and $10 \mathrm{nM}$, but not $100 \mathrm{nM}$, of paroxetine produced a much smaller inhibition of ${ }^{3} \mathrm{H}-5-\mathrm{HT}$ uptake than in slices from control rats (Fig. 12B).

\section{Effect of long-term paroxetine administration on ${ }^{3} \mathrm{H}$ - paroxetine binding parameters}

Specific saturable binding of ${ }^{3} \mathrm{H}$-paroxetine to rat cortical and hippocampal membranes was concentration dependent $(28 \%$ specific binding at $2 \mathrm{nM}{ }^{3} \mathrm{H}$-paroxetine). Scatchard transformation of the binding data produced linear plots in all cases (Fig. 13) and fitted better a one- rather than a two-site model. Mean $K_{d}$ and $B_{\max }$ values in control and long-term paroxetinetreated rats for both regions are summarized in Table 4 . After long-term paroxetine administration, the total number of binding sites was reduced by $60 \%$ in cortex and by $70 \%$ in hippocampus, thus confirming a downregulation of the 5-HT transporter. The fact that $K_{d}$ values remained unchanged after the treatment ruled out the possibility that the changes observed could be due to a competitive inhibition of binding by residual paroxetine after the $48 \mathrm{hr}$ washout period.

\section{Discussion}

Electrophysiological data obtained in the present study confirm and extend previous observations that $\mathrm{RT}_{50}$ values following 
A.

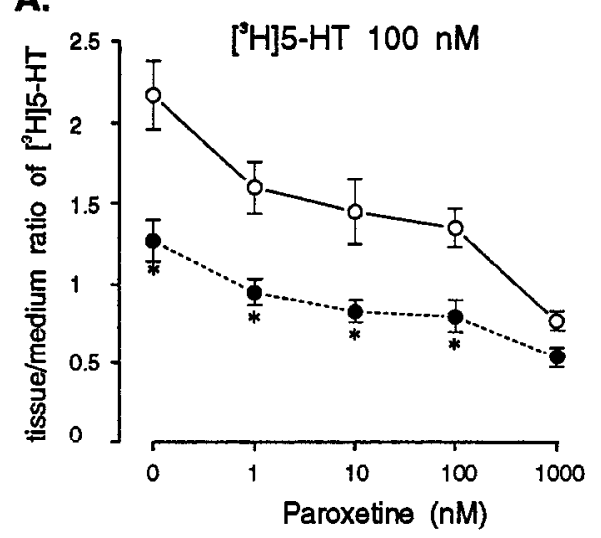

D.

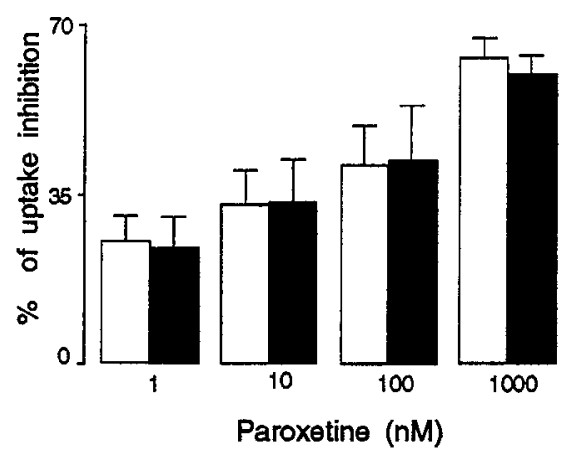

B.

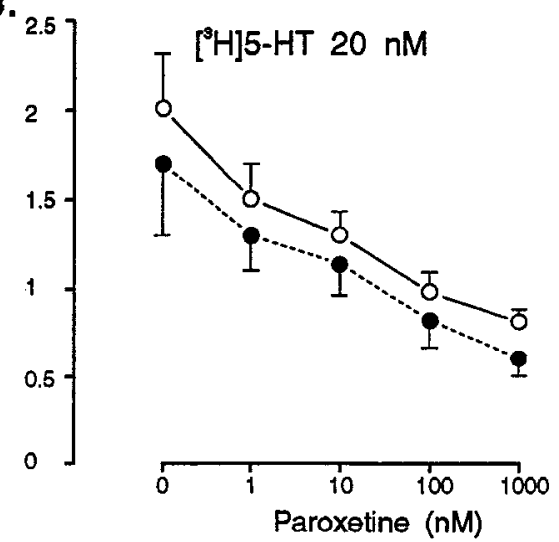

E.

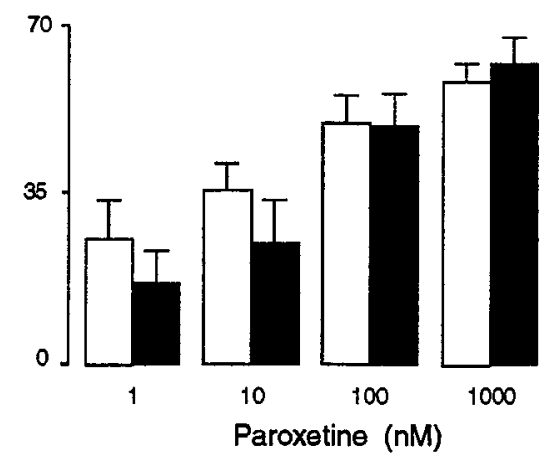

c.

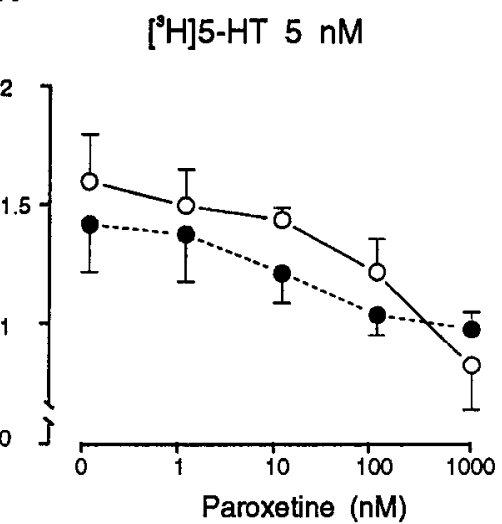

F.

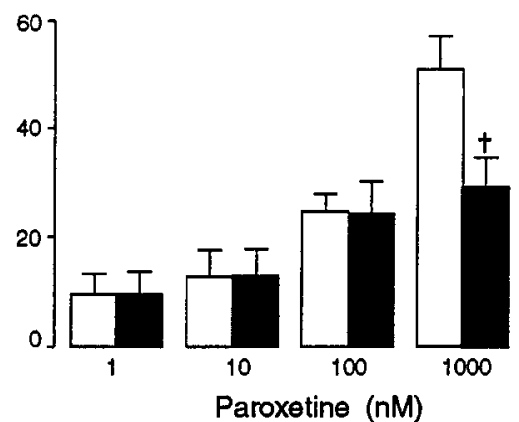

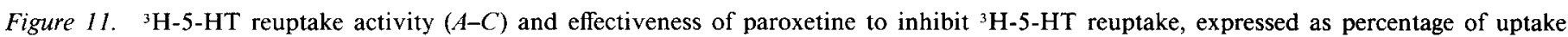

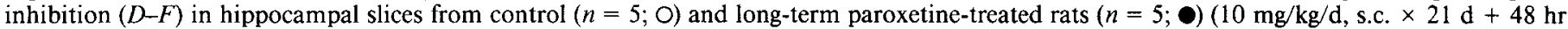

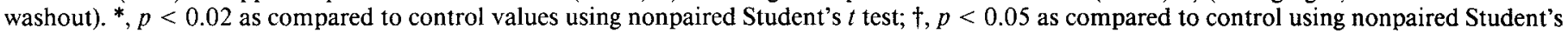
$t$ test.

microiontophoretic applications of 5-HT provide a reliable index of the in vivo activity of the 5-HT reuptake process, since it is prolonged three- to fourfold by acute, short-term, and longterm administration of paroxetine (Figs. 2,9) as well as by lesioning 5-HT terminals (Fig. 4). The fact that a selective 5-HT reuptake inhibitor (SSRI) prolongs recovery from 5-HT applications, leaving unaffected the effects of gepirone and NE (Table 1), which are not substrates for the 5-HT transporter, strongly suggests that the recovery of the firing frequency of pyramidal neurons following microiontophoretic applications of 5-HT depends on the activity of the 5-HT carrier. In a previous report we had concluded that, in dorsal hippocampus, 5-HT reuptake did not play a significant role in terminating the action of microiontophoretically applied 5-HT (de Montigny et al., 1980). The apparent contradiction between the latter report and the present one is probably due to the fact that, herein, microion- tophoretic applications were carried out using higher currents of a more concentrated solution of 5-HT to ensure that it would diffuse from the ejection site (near the cell body) to strata radiatum and oriens, where the majority of 5-HT terminals are located (Oleskevich and Descarries, 1990).

In keeping with previous observations that lesioning of 5-HT terminals abolishes ${ }^{3} \mathrm{H}$-paroxetine binding (de Souza and Kuyatt, 1987; Hrdina et al., 1990; Dewar et al., 1991), in our electrophysiological paradigm the 5,7-DHT pretreatment completely abolished the effect of acute paroxetine on the duration of suppression of firing activity by the microiontophoretic application of 5-HT (Fig. 4A). A similar effect was observed in vitro where paroxetine failed to decrease ${ }^{3} \mathrm{H}-5-\mathrm{HT}$ uptake in sliccs obtained from 5,7-DHT-lesioned rats (Fig. 10). Even if 5-HT transporters have been found in primary astrocyte cultures from neonatal rat brain (Kimelberg and Katz, 1985), the majority of

Table 4. Binding parameters of $\left[{ }^{3} \mathrm{H}\right]$ paroxetine in control and long-term paroxetine-treated rats

\begin{tabular}{llllll} 
& \multicolumn{2}{l}{ Kd $(\mathrm{nM})$} & & \multicolumn{2}{c}{ Bmax (fmol/mg of prot.) } \\
\cline { 2 - 3 } Brain region & Control & Paroxetine $^{*}$ & & Control & Paroxetine* \\
\hline Hippocampus & $0.3 \pm 0.05$ & $0.2 \pm 0.08$ & & $114 \pm 8$ & $31 \pm 9^{* *}$ \\
Cortex & $0.3 \pm 0.04$ & $0.2 \pm 0.06$ & & $138 \pm 19$ & $55 \pm 14^{* * *}$ \\
\hline
\end{tabular}

* $10 \mathrm{mg} / \mathrm{kg} /$ day, s.c. $\times 21$ days $+48 \mathrm{~h}$ washout.

${ }^{* *} p<0.001$, using two-tailed Student's $t$ test.

*** $p<0.01$, using two-tailed Student's $t$ test $(n=4)$. 
A.

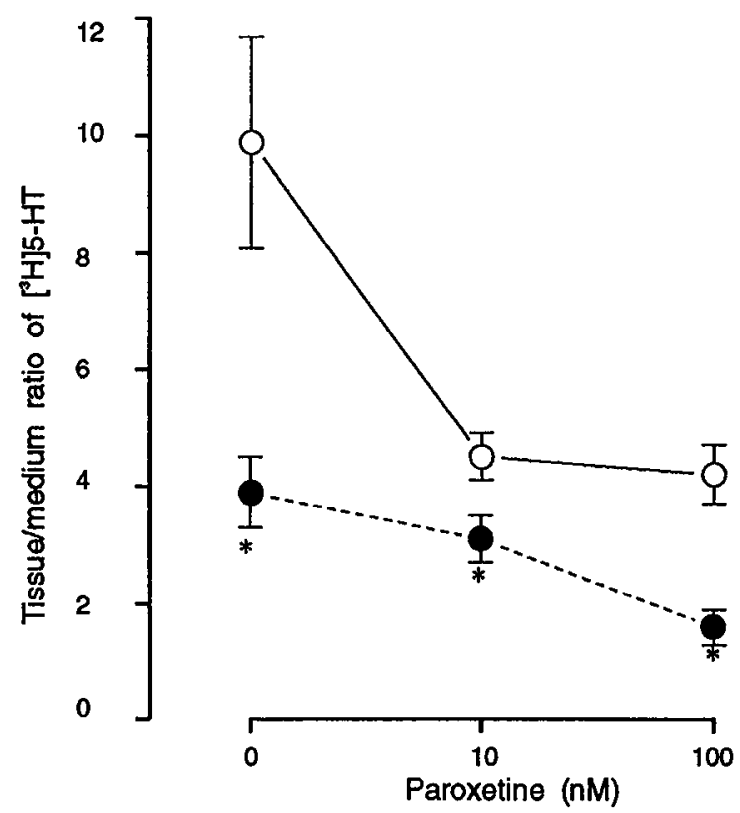

B.

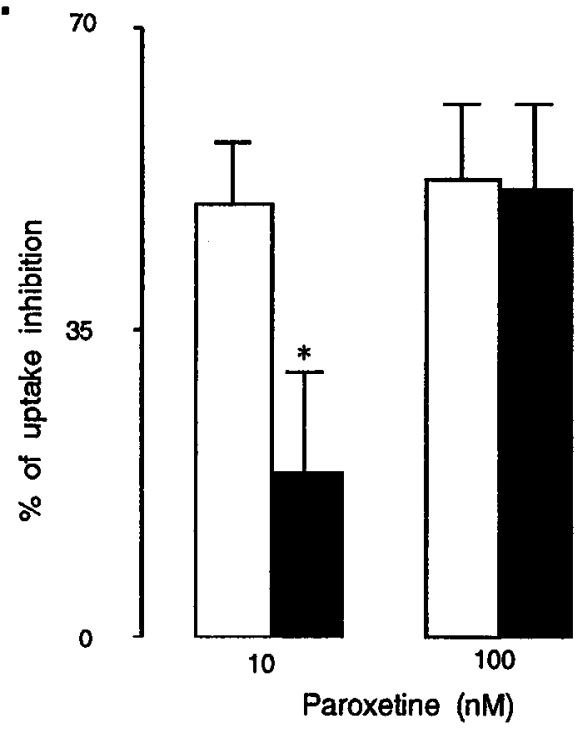

Figure $12 . \quad{ }^{3} \mathrm{H}-5-\mathrm{HT}$ reuptake $(A)$ and effectiveness of paroxetine to inhibit 5-HT reuptake $(B)$ in dorsal raphe slices from control $(O)$ and long-term paroxetine-treated rats $(0)(10 \mathrm{mg} / \mathrm{kg} / \mathrm{d}$, s.c. $\times 21 \mathrm{~d}+48 \mathrm{hr}$ washout; $N=6$ in each group). ${ }^{*}, p<0.05$ as compared to corresponding control values using nonpaired Student's $t$ test. The concentration of ${ }^{3} \mathrm{H}-5-\mathrm{HT}$ in the incubation medium was $100 \mathrm{~nm}$.

autoradiographic studies of ${ }^{3} \mathrm{H}-5-\mathrm{HT}$ reuptake in adult rat brain show that 5 -HT uptake by astrocytes is minimal relative to that by 5-HT terminals (Katz and Kimelberg, 1985). Our results further support the notion that functionally relevant transporters are confined to 5-HT terminals.

The electrophysiological paradigm we devised was not only sensitive enough to detect the effect of paroxetine on exogenously applied 5-HT through changes in $\mathrm{RT}_{50}$, but it could also detect the effect of 5-HT reuptake blockade on endogenously released 5-HT via the reduction of pyramidal neuron firing frequency (Figs. $1 B, 4 B, 5 A$ ). Since denervation abolished the consistent suppressant effect produced by paroxetine (Fig. $4 B$ ) on pyramidal neuron firing frequency, the latter observation clearly demonstrates the physiological role played by the 5-HT transporter in terminating the action of endogenously released 5-HT.

Long-term paroxetine treatment results in adaptive changes of the 5-HT transporter. These changes were detected not only in hippocampus (Figs. 7, 9,11) but also in cerebral cortex (Fig. 13) and in the raphe region (Fig. 12), indicating that 5-HT transporters in multiple pre- and postsynaptic regions of the rat CNS share the ability to adapt to their sustained occupation.

Though previous studies using ${ }^{3} \mathrm{H}$-imipramine have reported a decreased number of binding sites following long-term antidepressant treatment (Barbaccia et al., 1983; Arora and Meltzer, 1986; Brunello et al., 1987), these studies did not take into account the heterogeneity of ${ }^{3} \mathrm{H}$-imipramine binding sites. In the present study, the use of paroxetine as the tritiated ligand allows us to conclude that the changes observed are directly related to the 5-HT transporter as it has been shown to selectively label this carrier. In contrast with our observations, Graham et al. (1987), Brunswick et al. (1991), and Cheetham et al. (1991), using ${ }^{3} \mathrm{H}$-paroxetine, and Hrdina et al. (1990), taking into account high-and low-affinity ${ }^{3} \mathrm{H}$-imipramine binding sites, did not detect any change in $B_{\max }$ following long-term antidepressant treatment. These divergent results could be explained by the fact that in the aforementioned studies reuptake blockers were administered by intraperitoneal injections. Since SSRIs have been shown to be rapidly metabolized in rodents (Buus Lassen, 1978; Fredricson, 1982), intraperitoneal injections, given usually every 12 or $24 \mathrm{hr}$, lead to large fluctuations in drug plasma levels, and consequently in the degree of reuptake blockade. For example, for the SSRI citalopram, which in rats has a half-life of $3 \mathrm{hr}$ (Fredricson, 1982), its suppressant effect on the firing activity of 5-HT neurons is no longer detectable $15 \mathrm{hr}$ after the injection of a high dose (Chaput et al., 1986). The observation of the lack of 5-HT reuptake blockade $48 \mathrm{hr}$ after a $21 \mathrm{~d}$ treatment (Fig. 6) is thus fully consistent with the rapid metabolism of paroxetine in rodents (Buus Lassen, 1978). In the present study, to avoid fluctuations and produce stable plasma levels throughout the treatment period, paroxetine was administered by sustained subcutaneous infusion. Interestingly, Lesch et al. (1993) have recently reported the induction of downregulation of 5-HT transporter mRNA following long-term subcutaneous administration of fluoxetine, imipramine, and chlorimipramine. It therefore seems that stable plasma concentrations of the reuptake blocker administered are essential for the induction of an adaptive response at the level of the 5-HT transporter. Moreover, Kovachich et al. (1992) have reported that intraperitoneal administration of sertraline, but not that of citalopram, can reduce ${ }^{3} \mathrm{H}$-cyanoimipramine binding in different limbic regions. The fact that desmethylsertraline is more potent and has a longer half-life than mono- and dimethylated citalopram metabolites (Boyer and Feighner, 1991) further supports the notion that a sustained occupation is required to induce a downregulation of the neuronal 5-HT transporter. Since Lesch et al. (1993), using 5-HT reuptake inhibitors less potent than paroxetine, still observed a downregulation of the mRNA encoding the 5-HT transporter, it is improbable that uptake blocking capacity of the different SSRI might account for the differences between this and previous studies (Graham et al., 1987; Hrdina et al., 1990; Brunswick et al., 1991; Cheetham et al., 1991).

In the present electrophysiological experiments, desensitization of the 5-HT transporter in long-term paroxetine-treated rats was evidenced by a reduction in the effectiveness of acute 
A. HIPPOCAMPUS

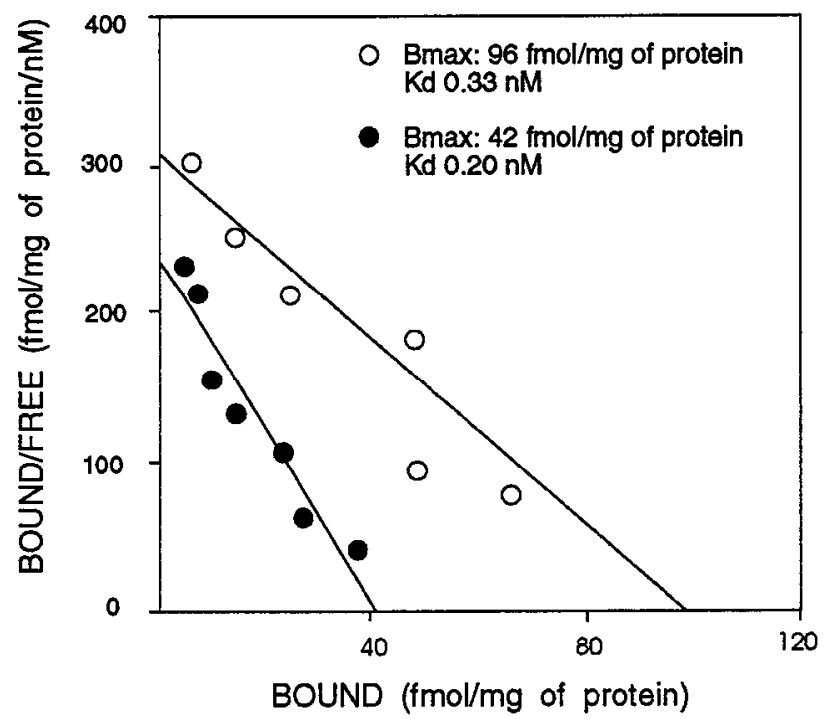

\section{B. CORTEX}

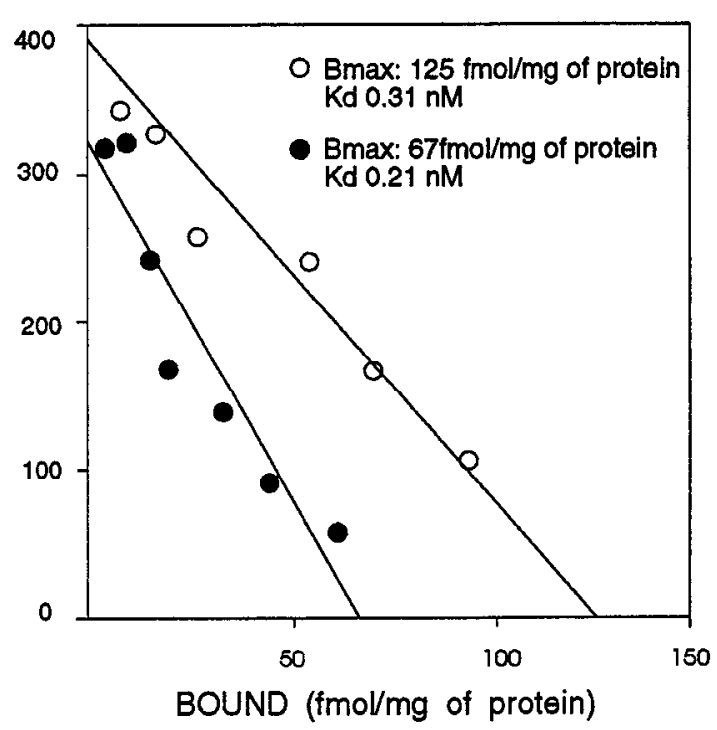

Figure 13. Representative Scatchard plots of specific ${ }^{3} \mathrm{H}$-paroxetine binding to hippocampal $(A)$ and cortical $(B)$ membranes in a control rat $(O)$ and in a rat treated with paroxetine $(0)(10 \mathrm{mg} / \mathrm{kg} / \mathrm{d}$, s.c. $\times 21 \mathrm{~d}+48 \mathrm{hr}$ washout $)$.

paroxetine to prolong the duration of suppression of firing by microiontophoretic applications of 5-HT (Fig. 7). Indeed, the $\mathrm{ED}_{50}$ of intravenous paroxetine to prolong $\mathrm{RT}_{50}$ was doubled in long-term paroxetine-treated rats (Table 3 ). Furthermore, the effect of subcutaneous administration of paroxetine on $\mathrm{RT}_{50}$ was significantly smaller in rats treated for $21 \mathrm{~d}$ than in those treated for $2 \mathrm{~d}$ (Fig. 9). Since the prolongation of $\mathrm{RT}_{50}$ values produced by $2 \mathrm{~d}$ subcutaneous administration of $10 / \mathrm{mg} / \mathrm{kg} / \mathrm{d}$ of paroxetine was similar in magnitude to that produced by a dose of $20 \mathrm{mg} /$ $\mathrm{kg} / \mathrm{d}$, it can be assumed that, at the dose of $10 / \mathrm{mg} / \mathrm{kg} / \mathrm{d}$, paroxetine blocked all available uptake sites. 'The fact that the effect of the $2 \mathrm{~d}$ treatment with $10 / \mathrm{mg} / \mathrm{kg} / \mathrm{d}$ of paroxetine was greater than that of the $21 \mathrm{~d}$ treatment suggests that the mechanism underlying this tolerance could be a reduction in the number of 5-HT transporters. This assumption was confirmed by radioligand binding studies that showed a $70 \%$ decrease in the number of ${ }^{3} \mathrm{H}$-paroxetine binding sites in hippocampal membranes following long-term paroxetine administration (Fig. 13A).

The current model for the 5-HT transporter proposes that 5-HT, tricyclic, and nontricyclic uptake inhibitors all bind to the same or overlapping sites on the carrier (Marcusson et al., 1989; Marcusson and Ross, 1990). There is an apparent discrepancy between the reduced effectiveness of acute injection of paroxetine (Fig. 7), the reduced ${ }^{3} \mathrm{H}-5$-HT uptake (Fig. 11), and the reduced number of ${ }^{3} \mathrm{H}$-paroxetine binding sites (Fig. 12) $48 \mathrm{hr}$ after the long-term paroxetine treatment, indicating a decrease in the number of 5-HT transporters, and the observation that, at this time point, the effect of microiontophoretically applicd 5-HT was not prolonged (Fig. 6). This could be explained by the presence of spare 5-HT transporters. Hence, even if the long-term paroxetine treatment downregulates 5-HT transporter sites, the number of remaining sites would be sufficient to take up all of the microiontophoretically applied 5-HT, even when applied with the highest current $(20 \mathrm{nA})$ used. This explanation is all the more likely since 5-HT is applied at the level of the soma, so that only minute amounts of the neurotransmitter would actually reach the 5-HT terminals, located mostly on remote dendritic trees. The existence of spare transporters could also explain the observation that, although paroxetine is a competitive antagonist for 5-HT reuptake, its $\mathrm{IC}_{50}$ was six times higher at $5 \mathrm{~nm}$ than at $100 \mathrm{nM}{ }^{3} \mathrm{H}-5-\mathrm{HT}$ concentrations. At the low ${ }^{3} \mathrm{H}-5$-HT concentration ( $5 \mathrm{nM}$ ), before interfering with ${ }^{3} \mathrm{H}-5-\mathrm{HT}$ uptake, paroxetine would first need to occupy a large number of sites, thus explaining the high $\mathrm{IC}_{50}$ values observed in these conditions. At the high ${ }^{3} \mathrm{H}-5-\mathrm{HT}$ concentration (100 nM), all (or most) of the transporters being operant, even low doses of paroxetine can interfere with reuptake. A reduction in the number of $5-\mathrm{H}^{\mathrm{T}}$ transporters could also explain the fact that $\mathrm{IC}_{50}$ values for paroxetine at different ${ }^{3} \mathrm{H}$ 5-HT concentrations did not differ any longer following longterm paroxetine treatment since the number of spare sites would be minimal.

The proportion of occupied/free transporters could then explain the different ways in which desensitization was expressed in the in vitro reuptake experiments (Fig. 11). At $100 \mathrm{nM}{ }^{3} \mathrm{H}-5$ $\mathrm{HT}$ (when all transporters are operant) a reduction in the number of sites was delected by reduction in ${ }^{3} \mathrm{H}-5-\mathrm{HT}$ uplake capacity, whereas at the low concentration of ${ }^{3} \mathrm{H}-5-\mathrm{HT}(5 \mathrm{nM})$, even in the presence of a reduced number of transporters, the remaining ones were in sufficient number to take up as much radioactivity as the control slices. Thus, in the latter condition, the reduction in the number of transporters was reflected by a decreased efficacy of the maximally effective paroxetine concentration (1000 nM).

The reduction in ${ }^{3} \mathrm{H}$-paroxetine binding sites after long-term paroxetine administration confirms the downregulation of 5-HT transporters. The fact that $K_{d}$ values were unchanged after treatment rules out the possibility of affinity changes being involved in the desensitization mechanism. This is in agreement with the observation that, even though paroxetine and 5-HT show different affinity for the 5-HT transporter, the present functional electrophysiological and uptake studies show that 5-HT reuptake activity and paroxetine effectiveness were reduced to a similar extent (45-60\%) after long-term reuptake blockade. 
Though $K_{d}$ values found with ${ }^{3} \mathrm{H}$-paroxetine in the present study were in the range of those previously reported by several groups, $B_{\max }$ values found in control rats were lower than those initially reported by Marcusson et al. (1988) for rat cortical membranes. However, values similar to those obtained in the present study were subsequently reported by Marcusson's group in the human cortex (Anderson et al., 1992) and by Foy et al. (1991) in rat diencephalon.

Blakely et al. (1991) and Haber and Goldman (1992) have cloned and expressed a 5-HT transporter from rat brain. Comparison of amino acid sequences demonstrates a $70 \%$ similarity between this protein and the NE transporter. In keeping with this observation, functional (Lacroix el al., 1991) and binding (Bauer and Tejani-Butt, 1992) assays of the NE transporter after long-term desipramine administration showed results similar to the ones observed for the 5-HT transporter in the present study. Therefore, monoaminergic transporters seem to possess common adaptive mechanisms elicited by their sustained occupation. Since long-term blockade of the 5-HT transporter induces a decrease in dorsal raphe mRNA codifying this protein (Lesch et al., 1993), the regulatory process most probably takes place at the transcriptional level.

In conclusion, the data presented in this study show (1) that the 5 -HT reuptake process can play a significant role in terminating the action of microiontophoretically applied 5-HT in the rat hippocampus and that the $\mathrm{RT}_{50}$ method provides a reliable index of the in vivo activity of this process; and (2) that the 5-HT transporter, though not a receptor per se, shares with some of them the characteristic of adapting to its sustained occupation through a downregulation mechanism. Thus, it is possible that the enhancement of the efficacy of 5-HT synaptic transmission following long-term administration of SSRIs would not only be due to desensitization of somatodendritic and terminal autoreceptors (Chaput et al., 1986), but also to a decrease in 5 -HT reuptake activity.

\section{References}

Anderson A, Eriksson A, Marcusson J (1992) Unaltered number of brain serotonin uptake sites in suicide victims. J Psychopharmacol 6:509-513.

Arora RC, Meltzer HY (1986) Effect of subchronic treatment with imipramine, chlorpromazine and the combination on $\left[{ }^{3} \mathrm{H}\right]$ imipramine binding in rat blood platelets and frontal cortex. Life Sci 39:22892296.

Barbaccia ML, Gandolfi O, Chuang D, Costa E (1983) Modulation of neuronal serotonin uptake by a putative endogenous ligand of imipramine recognition sites. Proc Natl Acad Sci USA 80:5134-5138.

Bauer ME, Tejani-Butt S (1992) Effects of repeated administration of desipramine or electroconvulsive shock on norepinepherine uptake sites measured by $\left[{ }^{3} \mathrm{H}\right]$ nisoxetine autoradiography. Brain Res 582 : 208-214.

Bjorklund A, Baumgarten HG, Rensch A (1975) 5,7-Dihydroxytryptamine: improvement of its selectivity for serotonin neurons in the CNS by pretrcatment with desipramine. $J$ Neurochem 24:833-835.

Blakely RD, Berson HE, Fremeau RT, Caron MG, Peek MM, Prince HK, Bradley CC (1991) Cloning and expression of a functional serotonin transporter from rat brain. Nature 354:66-70.

Boyer WF, Feighner JP (1991) Pharmacokinetics and drug interactions. In: Selective serotonin reuptake inhibitors (Feighner JP, Boyer WF, eds), pp. 81-88. New York: Wiley.

Brunel S, de Montigny C (1987) Diurnal rhythms in the responsiveness of hippocampal pyramidal neurons to serotonin, norepinephrine, $\gamma$-aminobutyric acid and acetylcholine. Brain Res Bull 18:205-212.

Brunello N, Riva M, Volterra A, Racagni G (1987) Effect of some tricyclic and nontricyclic antidepressants on $\left[{ }^{3} \mathrm{H}\right]$ imipramine binding and serotonin uptake in rat cerebral cortex after prolonged treatment. Fundam Clin Pharmacol 1:327-333.
Brunswick DJ, Kovachich GB, Aronson CE, Frazer A (1991) Effects of repeated administration on serotonin uptake sites measured using $\left[{ }^{3} \mathrm{H}\right]$ cyanoimipramine autoradiography In: Presynaptic receptors and neuronal transporters (I anger S7, Galzin AM, Costentin J, eds), pp 233-234. Oxford: Pergamon.

Buus Lassen J (1978) Potent and long-lasting potentiation of two 5-hydroxytryptophan-induced effects in mice by threc sclcctive uptake inhibitors. Eur J Pharmacol 47:351-358.

Chaput Y, de Montigny C, Blier P (1986) Effects of a selective 5-HT reuptake blocker, citalopram, on the sensitivity of 5-HT autoreceptors: electrophysiological studies in the rat brain. Naunyn Schmiedebergs Arch Pharmacol 333:342-348.

Cheetham SC, Viggers JA, Bucket WR (1991) Repeated antidepressant drug and electroconvulsive shock administration does not alter [ ${ }^{3}$ Hlparoxetine binding to rat frontal cortical membranes. Br J Pharmacol 102:242P.

de Montigny C, Aghajanian GK (1977) Preferential action of 5-methoxydimethyltryptamine on presynaptic serotonin receptors: a comparative iontophoretic study with LSD and 5-HT. Neuropharmacology 16:811-818.

de Montigny C, Wang RY, Rcader TA, Aghajanian GK (1980) Monoaminergic denervation of the rat hippocampus: microiontophoretic studies on pre- and postsynaptic supersensitivity to norepinephrine and serotonin. Brain Res 200:363-376.

de Souza EB, Kuyatt BL (1987) Autoradiographic localization of $\left[{ }^{3} \mathrm{H}\right]$ paroxetine-labelled serotonin uptake sites in rat brain. Synapse 1:488-496.

Dewar KM, Reader TA, Grondin L, Descarries L (1991) [ ${ }^{3} \mathrm{H}$ ]paroxetine binding and serotonin content of rat and rabbit cortical areas, hippocampus, neostriatum, ventral mesencephalic tegmentum, and midbrain raphe nuclei region. Synapse 9:14-26.

Foy B, Hepner E, Hrdina PD (1991) Relationship of $\left[{ }^{3} \mathrm{H}\right]$ paroxetine binding and 5-HT recognition sites on the neuronal serotonin transporter. In: Presynaptic receptors and neuronal transporters (Langer SZ, Galzin AM, Costentin J, cds), pp 231-232. Oxford: Pergamon.

Fredricson Overo K (1982) Kinetics of citalopram in test animals, drug exposure in safety studies. Prog Neuropsychopharmacol Biol Psychiatr 6:297-309.

Fuller RW, Wong DT (1990) Serotonin uptake and serotonin uptake inhibition. Ann NY Acad Sci 600:68-80.

Gerson S, Baldessarini RJ (1975) Selective destruction of serotonin terminals in rat forebrain by high doses of 5,7 dihydroxytryptamine. Brain Res 85:140-145.

Graham D, Tahraoui L, Langer SZ (1987) Effect of chronic treatment with selective monoamine oxidase inhibitors and specific 5-hydroxytryptamine uptake inhibitors on $\left[{ }^{3} \mathrm{H}\right]$ paroxetine binding to cerebral cortical membranes of the rat. Neuropharmacology 26:10871092.

Gravel P, de Montigny C (1987) Noradrenergic denervation prevents sensitization of rat forebrain neurons to tricyclic antidepressant treatment. Synapse 1:133-139.

Haber R, Goldman D (1992) Expression of size-selected RNA encoding brain serotonin transporter in Xenopus laevis oocytes. J Neurochem 58:1165-1167.

Habert E, Graham D, Tahraoui L, Claustre Y, Langer SZ (1985) Characterization of $\left[{ }^{3} \mathrm{H}\right]$ paroxetine binding to rat cortical membranes. Eur I Pharmacol 1 18:107-1 14.

Hrdina PD, Foy B, Hepner A, Summers RJ (1990) Antidepressant binding sites in brain: autoradiographic comparison of $\left[{ }^{3} \mathrm{H}\right]$ imipramine localization and relationship to serotonin transporter. J Pharmacol Exp Ther 252:410-418.

Johnson AM (1991) The comparative pharmacological properties of selective serotonin re-uptake inhibitors. In: Selective serotonin reuptake inhibitors (Feighner JP, Boyer WF, eds), pp 37-70. New York: Wiley.

Kandel ER, Spencer WA (1961) Electrophysiology of hippocampal neurons. II. After-potentials and repetitive firing. J Neurophysiol 24: 243-259.

Katz DM, Kimelberg HK (1985) Kinetics and autoradiography of high affinity uptake of serotonin by primary astrocyte cultures. J Neurosci 5:1901-1908.

Kimelberg HK, Katz DM (1985) High affinity uptake of serotonin into immunocytochemically identified astrocytes. Science 228:889891.

Kovachich GB, Aronson CE, Brunswick DJ (1992) Effect of repeated administration of antidepressants on serotonin uptake sites in limbic 
and neocortical structures of rat brain determined by quantitative autoradiography. Neuropsychopharmacology 7:317-324.

Lacroix D, Blier P, Curet O, de Montigny C (1991) Effects of longterm desipramine administration on noradrenergic neurotransmission: electrophysiological studies in the rat brain. J Pharmacol Exp Ther 257:1081-1090.

Langer SZ, Raisman R (1983) Binding of $\left[{ }^{3} \mathrm{H}\right]$ imipramine and $\left[{ }^{3} \mathrm{H}\right]$ desipramine as biochemical tools for studies in depression. Neuropharmacology 22:407-413.

Lesch KP, Aulakh CS, Wolozin BJ, Tolliver TJ, Hill JL, Murphy DL (1993) Regional brain expression of serotonin transporter mRNA and its regulation by reuptake inhibiting antidepressants. Mol Brain Res 17:31-35.

Marcusson JO, Ross SB (1990) Binding of some antidepressants to the 5-hydroxytryptamine transporter in brain and platelets. Psychopharmacology 102:145-155.

Marcusson JO, Fowler CJ, Hall H, Ross SB, Winblad B (1985) "Specific" binding of $\left[{ }^{3} \mathrm{H}\right]$ imipramine to protease sensitive and protease resistant sites. J Neurochem 44:705-711.

Marcusson JO, Bergstrom M, Eriksson K, Ross SB (1988) Characterization of $\left[{ }^{3} \mathrm{H}\right]$ paroxetine binding in rat brain. $\mathrm{J}$ Neurochem 50 : 1783-1790.
Marcusson JO, Andersson A, Backstrom I (1989) Drug inhibition indicates a single-site model of the 5-HT uptake site/antidepressant binding site in rat and human brain. Psychopharmacology 99:17-21.

Mellerup E, Plenge P (1986) High affinity binding of $\left[{ }^{3} \mathrm{H}\right]$ paroxetine and $\left[{ }^{3} \mathrm{H}\right]$ imipramine to rat neuronal membranes. Psychopharmacology 89:436-439.

Oleskevich S, Descarrics L (1990) Quantified distribution of the serotonin innervation in adult rat hippocampus. Neuroscience 34:1933.

Plenge P, Mellerup ET (1982) $\left[{ }^{3} \mathrm{H}\right]$ imipramine high-affinity binding sites in rat brain. Effects of imipramine and lithium. Psychopharmacology 77:94-98.

Ranck JB (1975) Behavioral correlates and firing repertoires of neurons in the dorsal hippocampal formation of unrestrained rats. In: The hippocampus (Isaacson I, Robert L, eds), p 207. New York: Plenum.

Reith MEA, Sershen H, Allen D, Lajtha A (1983) High and low affinity binding of $\left[{ }^{3} \mathrm{H}\right]$ imipramine in mouse cerebral cortex. J Neurochem 102:389-395.

Wang RY, de Montigny C, Gold BI, Roth RH, Aghajanian GK (1979) Denervation supersensitivity to serotonin in rat forebrain: single cell studies. Brain Res 178:479-497. 